\title{
Chelation-Assisted Regioselective C-O Bond Cleavage Reactions of Acetals by Grignard Reagents. A General Procedure for the Regioselective Synthesis of Protected Polyols Having One Free Hydroxy Group
}

\author{
Wen-Lung Cheng, Yeng-J eng Shaw, Sue-Min Yeh, Puthuparampil P. Kanakamma, \\ Yu-Huey Chen, Chuo Chen, J ia-Cheng Shieu, Shaang-J yh Yiin, Gene-Hsiang Lee, \\ Yu Wang, and Tien-Yau Luh* \\ Department of Chemistry, National Taiwan University, Taiped, Taiwan 106
}

Received August 4, 1998

\begin{abstract}
Acetals containing a neighboring heteroatom react with the Grignard reagent in aromatic hydrocarbon solvents regioselectively. The auxiliary moiety can be hydroxy, alkoxy, or amino but not sulfur. Chelation plays a key role in directing the regioselectivity of this ring opening reaction. The reactions of acetonide derivatives of monosaccharides under these conditions afford the corresponding products having only one free hydroxy group at the specific position. Fully protected mannosamine derivative is prepared in good yield. The stereochemistry of the carbon center where auxiliary group is attached can be either syn or anti to the acetal oxygen moiety where cleavage of the $\mathrm{C}-\mathrm{O}$ bond occurs. However, difference in reactivity has been found in the reaction of trisacetonide of sorbitol with $\mathrm{MeMgl}$. Regioselective ring opening of the acetal group at the anomeric carbon generates a hemiacetal which underwent further nucleophilic addition to furnish the corresponding alcohol stereoselectively.
\end{abstract}

Differentiation of a contiguous polyol by the regioselective protection leading to the product having only one or two free hydroxy group(s) at the selected position(s) is valuable in synthesis. ${ }^{1}$ Acetal and ortho ester functionalities are widely used protective groups for such polyols. Direct transformation of a polyol into the corresponding acetal or ortho ester leaving certain hydroxy groups intact would be the ideal situation but successful only in limited cases. ${ }^{2}$ Multistep protection and deprotection are occasionally required. Sel ective conversion of an acetal moiety with a nucleophile into a hydroxyalkyl ether serves as a practical arsenal for this purpose. ${ }^{3-11}$ The reaction has been demonstrated to be particularly important for the diastereosel ective ring opening of cyclic

(1) Greene, T. A.; Wuts, P. G. M. Protective Groups in Organic Synthesis, 2nd ed.; Wiley: New York, 1991. (b) Kocienski, P. J . Protective Groups; Thieme: New York, 1994.

(2) For a recent review, see: Hanessian, S., Ed.; Preparative Carbohydrate Chemistry; Marcel Dekker: New York, 1997. See also: Lee, H. W.; Kish, Y.J . Org. Chem. 1985, 50, 4402.

(3) (a) Bartlett, P. A.; J ohnson, W. S.; Elliott, J. D. J . Am. Chem. Soc. 1983, 105, 2088. (b) Mori, A.; Fujiwara, J .; Maruoka, K.; Yamamoto, H. Tetrahedron Lett. 1983, 24, 4581.

(4) (a) Takano, S.; Kurotaki, A.; Sekiguchi, Y.; Satoh, S.; Hirama, M.; Ogasawara, K. Synthesis 1986, 811. (b) Takano, S.; Akiyama, M.; Ogasawara, K. Chem. Pharm. Bull. 1984, 32, 791. (c) Takano, S. Akiyama, M.; Sato, S.; Ogasawara, K. Chem. Lett. 1983, 1593. (d) Takano, S.; Ohkawa, T.; Ogasawara, K. Tetrahedron Lett. 1988, 29, 1823. (e) Gilbert, I. H.; Holmes, A. B.; Young, R. C. Tetrahedron Lett. 1990, 31, 2633. (f) Gilbert, I. H.; Holmes, A. B.; Pestchanker, N. J .; Young, R. C. Carbohydr. Res. 1992, 234, 117.

(5) (a) Mori, I.; I shihara, L. A.; Flippin, L. A.; Nozaki, K.; Yamamoto, H.; Bartlett, P. A.; Heathcock, C. H. J . Org. Chem. 1990, 55, 6107. (b) Denmark, S. E.; Almstead, N. G. J . Am. Chem. Soc. 1991, 113, 8089; J. Org. Chem. 1991, 56, 6458, 6485. (c) Sammakia, T.; Smith, R. S. J . Org. Chem. 1992, 57, 2997; J. Am. Chem. Soc. 1992, 114, 10998.

(6) (a) Blomberg, C.; Vreugdenhil, A. D.; Homsma, T. Recl. Trav. Chim. 1963, 82, 355. (b) Mallory, R. A.; Rovinski, S.; Scheer, I. Proc. Chem. Soc. London 1964, 416.

(7) For reviews, see: (a) Trofimov, B. A.; Korostova, S. E. Russ. Chem. Rev. 1975, 44, 41. (b) Mukaiyama, T.; Murakami, M. Synthesis 1987, 1043. (c) Alexakis A.; Mangeney, P. Tetrahedron: Asymmetry 1990, 1, 477. (d) Luh, T.-Y. Pure Appl. Chem. 1996, 68, 635. (e) Luh, T.-Y. Synlett 1996, 201. chiral acetals. ${ }^{3}$ Lewis acids are occasionally used to assist such reactions. Reductive cleavage of benzylidene acetals or the like has been used for the regiosel ective synthesis of certain monosaccharide derivatives. ${ }^{8}$ Trimethylaluminum has been employed to facilitate the alkylative ring opening reaction. ${ }^{5}$ However, a mixture of regioisomers is occasionally obtained. Although reactions of the Grignard reagent with acetals have been known for more than three decades ${ }^{5}$ and the mechanism for this transformation has been extensively investigated, ${ }^{6}$ not much synthetic use has been reported..$^{5,7}$ We recently uncovered a convenient synthesis of tunable $\mathrm{C}_{2}$-chiral diols $\mathbf{3}$ by the regioselective ring opening of bisketals of threitol $\mathbf{1}$ with a variety of Grignard reagents in benzene (eq 1). ${ }^{9}$

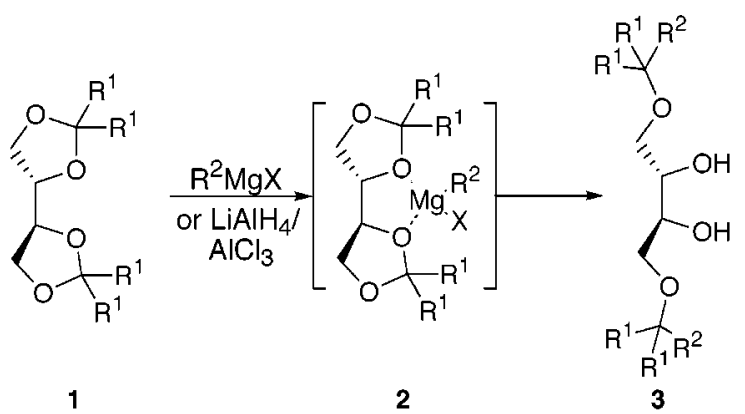

Applications of this strategy to the synthesis of myoinositol derivatives having one or two free hydroxy group-

(8) Garegg, P. J . PureAppl. Chem., 1984, 56, 845. Garegg, P. J . Acc. Chem. Res. 1992, 25, 575. For chelative reductive cleavage of acetals, see: Evans, D. A.; Kaldor, S. W.; J ones, T. K.; Clardy, J .; Stout, T. J. J. Am. Chem. Soc. 1990, 112, 7001. Takano, S.; Kurotaki, A.; Sekiguchi, Y.; Satoh, S.; Hirama, M.; Ogazawara, K. Synthesis 1986, 811.

(9) Yuan, T.-M.; Hsieh, Y.-T.; Yeh, S.-M.; Shyue, J.- . .; Luh, T.-Y. Synlett 1996, 53.

(10) Yeh, S.-M.; Lee, G.-H.; Wang, Y.; Luh, T.-Y.J . Org. Chem. 1997, 62,8315 
(s) have been executed (eq 2)..$^{10}$ The Grignard reagent can vary among primary, secondary, and arylmagnesium halides. It is believed that chelation has played a key role in directing the regioselectivity of this ring opening reaction. Accordingly, a possible chelation intermediate

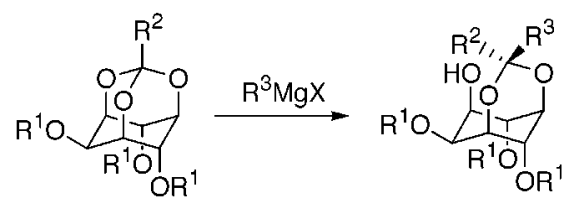

2 has been postulated to rationalize the sel ectivity of this reaction. We felt that this reaction could be extended to the selective protection/deprotection of various polyhydroxy-compounds having only one or two free hydroxyl group. Described herein is a full account which demonstrates a useful regioselective ring-opening reaction of acetals with Grignard reagents. ${ }^{11}$

\section{Results and Discussion}

Prototype. On the basis of the chelation strategy depicted above (eq 1), acetonides can be cl eaved regioselectively with Grignard reagents when a neighboring heteroatom is present. ${ }^{11}$ Accordingly, selective cleavage of one of the two $\mathrm{C}-\mathrm{O}$ bonds in the acetal-protected monosaccharides will offer a powerful arsenal for the selective synthesis of various monosaccharide derivatives having only one free hydroxy group at the specific position.

In the beginning of this investigation, we compared the selectivity of the ring opening reactions of unchelated acetonides to those of chelated ones. Thus, acetals $\mathbf{4}$ were treated with 4 equiv of $\mathrm{MeMgl}$ in refluxing benzene-ether (5:1) for $20 \mathrm{~h}$. After the usual workup procedure, the corresponding hydroxyalkyl ethers $\mathbf{5}$ were obtained in good yields (eq 3). ${ }^{4}$ Both five- and six-membered aceto-

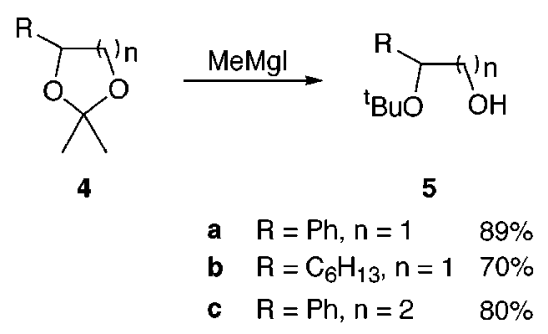

nides behaved similarly and the $\mathrm{C}-\mathrm{O}$ bond of the lesshindered site in $\mathbf{4}$ was cleaved regiosel ectively. Presumably, the oxygen atom on this site would coordinate to magnesium preferentially, resulting in the regioselective protection of the morehindered hydroxy group of the diol.

The presence of a neighboring oxygen or nitrogen moiety changed the selectivity of the ring-opening reaction. For example, the reaction of $\mathbf{6}$ with $\mathrm{MeM}$ gl afforded the corresponding diol 7 in $78 \%$ yield (eq 4). The neighboring amino group behaved similarly (eq 5). As

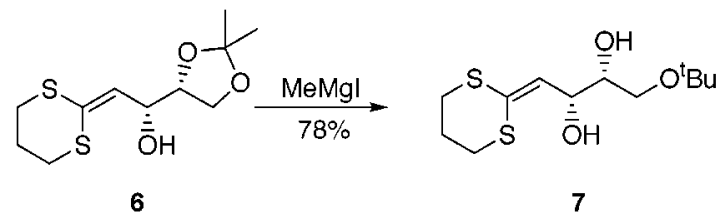

depicted in eq 1 , the hydroxy group in $\mathbf{6}$ or the amino group in $\mathbf{8}$ apparently plays a pivotal role in determining

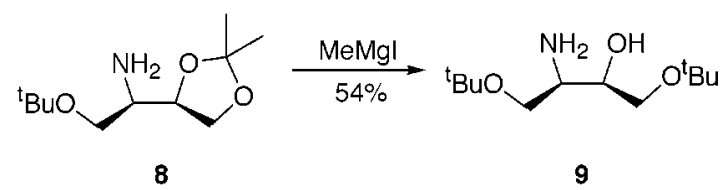

the regioselectivity of the ring opening reaction. The stereochemistry in $\mathbf{9}$ was unambiguously proved by X-ray diffraction (Figure 1, Supporting I nformation).

When bis-acetonide $\mathbf{1 0}$ was treated with $\mathrm{MeMgl}$ in benzene at $60{ }^{\circ} \mathrm{C}$, mono-hydroxy compound $\mathbf{1 1}$ was obtained in $48 \%$ yield (eq 6). Mannitol derivative 12 was

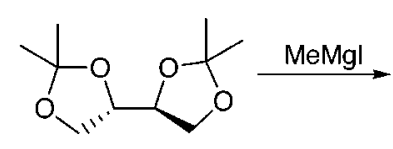

10

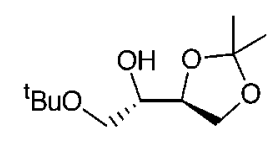

11 transformed into the corresponding mono-hydroxy product $\mathbf{1 3}$ in refluxing benzene (eq 7). When more drastic conditions were employed, diol $\mathbf{1 4}$ was isolated in good yield (eq 7). When an unsymmetrical bis-acetonide $\mathbf{1 5}$

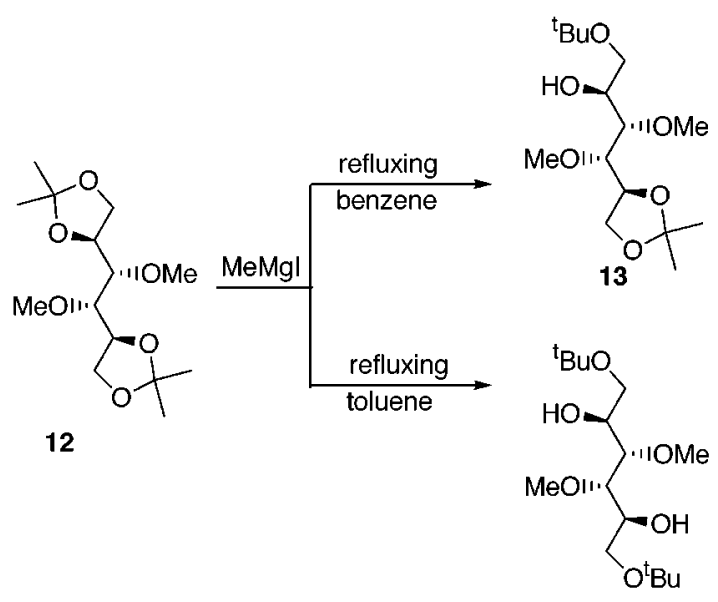

was employed, the less hindered heterocycle underwent alkylative ring opening (eq 8). This protocol serves as a powerful arsenal for the synthesis of various carbohydrate derivatives having selectively one free hydroxy group at the specific position.

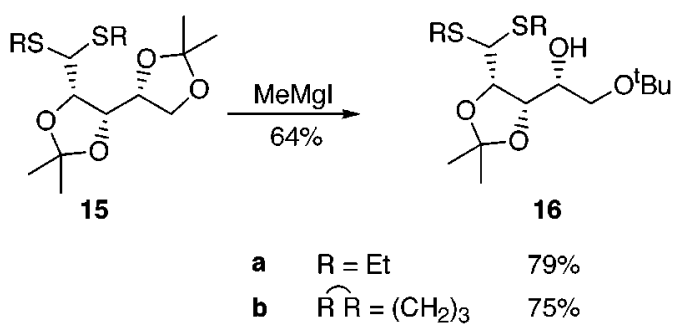

Stereochemistry of the Auxiliary. As can be seen from eqs $4-7$, the stereochemistry of the carbon center where auxiliary group is attached can be either syn or anti to the acetal oxygen moiety where cleavage of the $\mathrm{C}-\mathrm{O}$ bond occurs. In a si milar manner, stereoisomers $\mathbf{1 7}$

(11) For preliminary communications, see: Cheng, W.-L.; Yeh, S.M.; Luh, T.-Y. J . Org. Chem. 1993, 58, 5576. Chen, Y.-H.; Luh, T.-Y.; Lee, G.-H.; Peng, S.-M. J . Chem. Soc., Chem. Commun. 1994, 2369. 
and $\mathbf{1 9}$ were transformed into respective diols $\mathbf{1 8}$ and $\mathbf{2 0}$ smoothly upon treatment with $\mathrm{MeMgl}$ (eqs 9 and 10).

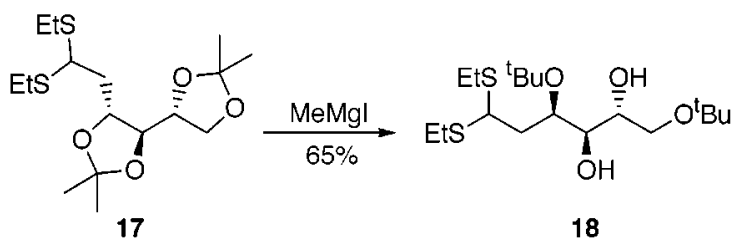

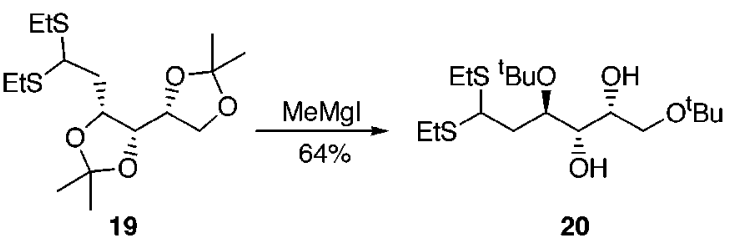

However, difference in the reactivity has been found in the reaction of tris-acetonide of sorbitol $\mathbf{2 1}$ with $\mathbf{M e M g l}$ (eq 11). The structure of product $\mathbf{2 2}$ was determined by $X$-ray crystallography of the corresponding benzyl ether 23 (Figure 2, Supporting Information). 5-Hydroxy derivative $\mathbf{2 4}$ was not detected.

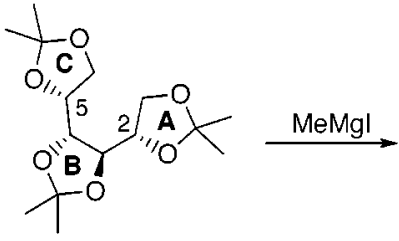

21

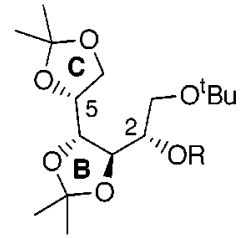

$22 \mathrm{R}=\mathrm{H}$
$23 \mathrm{R}=\mathrm{Bn}$

The regioselectivity of the reaction of $\mathbf{2 1}$ can be rationalized by considering the relative stability of the chelation intermediates $\mathbf{2 5}$ and $\mathbf{2 6 .}{ }^{12}$ In $\mathbf{2 5}$, the magnesium chelates with the oxygen atoms at $\mathrm{C}_{4}$ and $\mathrm{C}_{5}$ which will lead to the formation of $\mathbf{2 4}$. The relative configuration<smiles>CC(C)(C)OC(C(O)CO)[C@@H]1COC1(C)C</smiles>

at $C_{4}$ and $C_{5}$ can be considered as meso form of a threitol derivative. As can be seen from $\mathbf{2 5}$, severe steric interaction might be expected between the two endo-methyl groups and the endo-ligand on magnesium. Intermediate $\mathbf{2 6}$ on alkylative ring opening will furnish $\mathbf{2 2}$. Since only

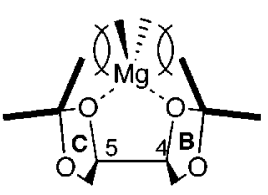

25

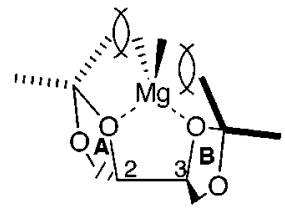

26 one of the endo-methyl groups will interact with one of the ligands on magnesium in $\mathbf{2 6}$, the steric repulsion

(12) Alternatively, the formation of complexes $\mathbf{2 5}$ and $\mathbf{2 6}$ may be fast and reversible and the Curtin-Hammett principle may apply for the rationalization of the selectivity. might be expected to be less than that in $\mathbf{2 5}$. Accordingly, chelation intermediate $\mathbf{2 6}$ may be formed preferentially and determine the sel ectivity.

Monosaccharide Derivatives Having One Free Hydroxy Group. I n our prel iminary communication, we disclosed the usefulness of the chelation-controlled selective alkylative ring-opening of acetonides of methyl glucosides 27 (eq 12). ${ }^{11}$ The reaction provides a useful entry toward a glucoside derivative $\mathbf{2 8}$ having a free hydroxy group at $\mathrm{C}_{2}$. The chelation of the anomeric

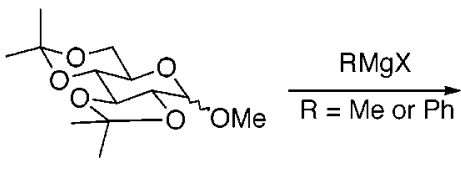

27

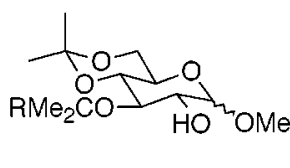

28 methoxy group and the neighboring oxygen function at $\mathrm{C}_{2}$ in $\mathbf{2 7}$ with magnesium may explain the results. It is noteworthy that the anomeric methoxy group can be either $\alpha$ or $\beta$. Furthermore, the trans-fused five-membered acetonide moiety in $\mathbf{2 7}$ apparently is more reactive because the steric strain will be released upon alkylative ring-opening reaction.

The extension of this reaction to allyl glucoside 29 also afforded the corresponding mono-hydroxy derivative $\mathbf{3 0}$. Further transformations ${ }^{13}$ led to a convenient synthesis of fully protected mannosamine $\mathbf{3 1}$ (eq 13).

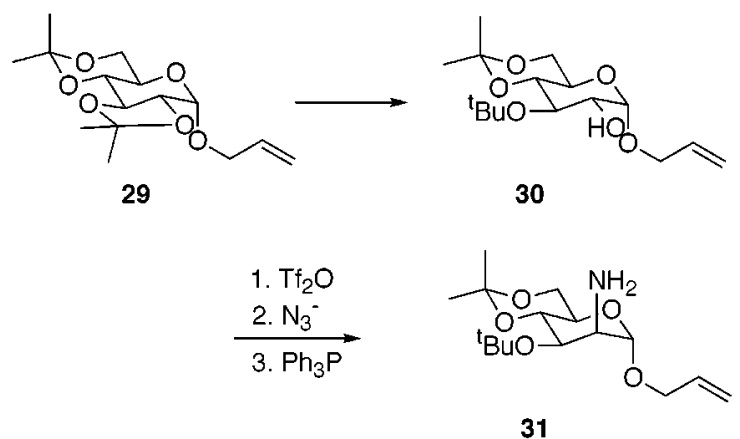

Upon treatment with with $\mathrm{MeMgl}$, glucosides $\mathbf{3 2}$ and 34 afforded 33 and 35 in 58\% and 55\% yield, respectively.

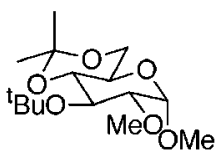

32

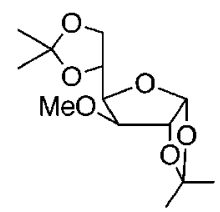

34

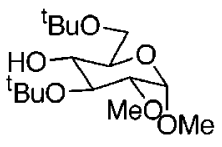

33

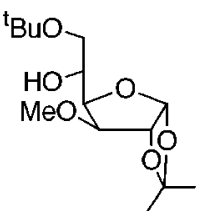

35
The presence of a $\beta$-methoxy group at $\mathrm{C}_{3}$ in $\mathbf{3 4}$ seems to be irrelevant for the selectivity of this ring-opening process because the reaction of allose derivative $\mathbf{3 6}, \mathrm{a}_{3}$ epimer of 34, al so afforded $54 \%$ yield of the corresponding $5-\mathrm{OH}$ product 37. These results suggested that chelation

(13) Knouzi, N.; Vaultier, M.; Carrié, R. Bull. Soc. Chim. Fr. 1985 $5,815$. 
with the oxygen atom on the five-membered furanose heterocycle may play a pivotal role in these reactions.

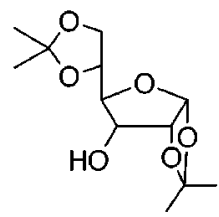

36

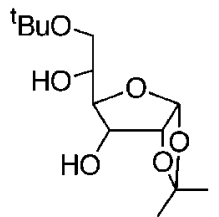

37
Galactose derivative $\mathbf{3 8}$ was converted into the 4-hydroxy derivative 39 in $52 \%$ yield. Presumably, chelation with the methoxy group at $\mathrm{C}_{6}$ controls the regioselectivity. The conformational rigidity may prohibit chelate formation with oxygen atoms attached at $C_{2}$ and $C_{3}$ in 38.

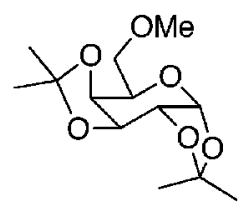

38

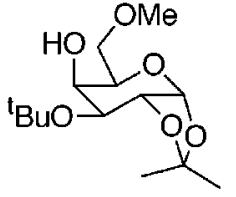

39
Treatment of mannose derivative $\mathbf{4 0}$ with $\mathbf{M e M g l}$ in refluxing benzene for $24 \mathrm{~h}$ afforded $\mathbf{4 1}$ in $51 \%$ yield. Intermediate $\mathbf{4 2}$ was isolated when the same reaction was carried out for $3 \mathrm{~h}$.

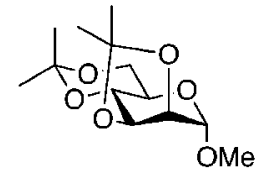

40

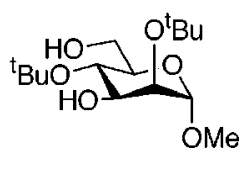

41

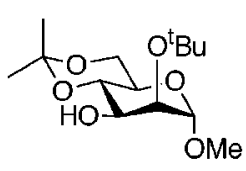

42
Reactions at the Anomeric Center. Stereoselective displacement of one of the carbon-oxygen bonds by a carbon-carbon bond at the anomeric center paves the way for the synthesis of C-glycosides. The use of acetal protective group for the anomeric hydroxy group abounds. Accordingly, regioselective ring opening of the acetal group at the anomeric carbon will generate a hemiacetal which can further react with the nucleophile leading to an alcohol stereoselectively. This idea was executed with fructopyranose and arabinopyranose derivatives 43-45.<smiles>COCC12OC(C)(C)OC1C1OC(C)(C)OC12</smiles>

43<smiles>CC1(C)OC2C(O1)C1OC(C)(C)OC21</smiles>

45

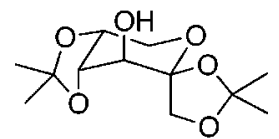

44

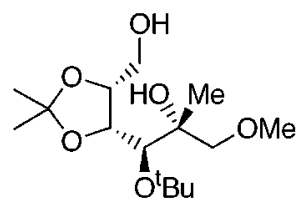

46
By considering the structure of fructopyranose $\mathbf{4 3}$ the methoxy group at $C_{1}$ would assist the cleavage to occur at $\mathrm{C}_{2}$. Thus, treatment of $\mathbf{4 3}$ with $\mathbf{M e M g l}$ under usual conditions gave $\mathbf{4 6}$ selectively in $\mathbf{7 5 \%}$ yield. Presumably, the reaction produces intermediate $\mathbf{4 7}$ which will further react with $\mathrm{MeMgl}$ stereoselectively to yield $\mathbf{4 6}$. In a<smiles>CCO[C@@H](C(=O)COC)[C@H]1OC(C)(C)O[C@@H]1CO</smiles>

47<smiles>CCCCOC(=O)C(O)[C@H]1OC(C)(C)O[C@@H]1CO</smiles>

48<smiles>[R16][C@H](O)[C@@]([Y4])(O)[C@H](O)[C@H]1OC(C)(C)O[C@H]1CO</smiles>

49

similar manner, the hydroxy group at $\mathrm{C}_{3}$ in $\mathbf{4 4}$ can also aid the regioselective ring opening of the acetonide at $C_{2}$. Accordingly, the reaction of $\mathbf{4 4}$ with $\mathbf{M e M g l}$ in refluxing benzene afforded al cohol 49 in 55\% yield. Intermediate $\mathbf{4 8}$ may be involved and further transformed into $\mathbf{4 9}$ by excess $\mathrm{MeMgl}$. The stereosel ectivities in both reactions can readily be rationalized by means of chelation with the neighboring oxygen function.

Arabinose derivative $\mathbf{4 5}$ does not have a neighboring oxygen atom for chelate formation with magnesium. In addition, both acetonide rings are cis fused with the perhydropyran ring. In a manner similar to that described in eq 4, the least-hindered $\mathrm{C}-\mathrm{O}$ bond in $\mathbf{4 5}$ was cleaved selectively and the hemiacetal $\mathbf{5 1}$ thus generated reacted with an additional mole of the Grignard reagent to yield $\mathbf{5 0}$ stereoselectively.<smiles>CCCC(C)(O)[C@@H](O)[C@H]1OC(C)(C)O[C@@H]1CO</smiles>

50<smiles>CCCCC1C(O)C(O)C2OC(C)(C)OC12</smiles>

51

\section{Conclusions}

In summary, we have demonstrated a useful simple procedure using the Grignard reagent to partially deprotect acetonides of vicinal diols leading to the corresponding tert-butyl hydroxyalkyl ethers regi oselectively. Chelation has played a pivotal role to direct the regioselectivity of this ring opening process. The reaction offers a powerful arsenal in selective protection-deprotection of hydroxy groups in carbohydrates leading to various monosaccharide derivatives having only one free hydroxy group at the specific position.

\section{Experimental Section}

General Procedure for Reactions of Acetonides with Grignard Reagent. To a solution of acetonide in benzene under $\mathrm{N}_{2}$ was added, in one portion, the Grignard reagent (4 equiv). The mixture was stirred at $60{ }^{\circ} \mathrm{C}$ or heated under reflux, and the reaction was monitored by TLC. The cooled mixture was poured into water, and the organic layer was separated. The aqueous solution was extracted with $\mathrm{Et}_{2} \mathrm{O}$, and the organic layers were washed with $10 \%$ aqueous $\mathrm{NaOH}$, water, and brine and dried $\left(\mathrm{MgSO}_{4}\right)$. The solvent was evapo- 
rated in vacuo, and the residue was chromatographed on silica gel to afford the product.

2-tert-B utoxy-2-phenylethanol (5a). In a manner similar to that described in the general procedure, a benzene solution of $4 \mathrm{a}$ (310 mg, $1.2 \mathrm{mmol}$ ) with $\mathrm{MeMgl}\left(2.4 \mathrm{~mL}, 2.0 \mathrm{M}\right.$ in $\mathrm{Et}_{2} \mathrm{O}$, $4.8 \mathrm{mmol}$ ) was refluxed for $20 \mathrm{~h}$ to give $5 \mathbf{a}^{14}$ (300 $\mathrm{mg}, 89 \%$ ): ${ }^{1} \mathrm{H} \mathrm{NMR}\left(\mathrm{CDCl}_{3}, 300 \mathrm{MHz}\right) \delta 1.14(\mathrm{~s}, 9 \mathrm{H}), 2.26(\mathrm{dd}, \mathrm{J}=3.8$, $9.4 \mathrm{~Hz}, 1 \mathrm{H}), 3.45-3.52(\mathrm{~m}, 2 \mathrm{H}), 4.60(\mathrm{dd}, \mathrm{J}=4.5,8.2 \mathrm{~Hz}, 1$ $\mathrm{H}), 7.21-7.45(\mathrm{~m}, 5 \mathrm{H}) ;{ }^{13} \mathrm{C} \mathrm{NMR}\left(\mathrm{CDCl}_{3}, 50 \mathrm{MHz}\right) \delta 28.8,67.8$, 74.9, 75.4, 126.3, 127.3, 128.2, 142.2.

2-tert-Butoxyoctan-1-ol (5b). In a manner similar to that described in the general procedure, the reaction of $\mathbf{4 b}$ (438 $\mathrm{mg}, 2.4 \mathrm{mmol})$ with $\mathrm{MeMgl}\left(4.8 \mathrm{~mL}, 2.0 \mathrm{M}\right.$ in $\mathrm{Et}_{2} \mathrm{O}, 9.6$ $\mathrm{mmol}$ ) in refluxing benzene for $20 \mathrm{~h}$ afforded $\mathbf{5} \mathbf{b}^{15}$ (343 $\mathrm{mg}$, $70 \%)$ : bp $80^{\circ} \mathrm{C}(1 \mathrm{mmHg}) ;{ }^{1} \mathrm{H} \mathrm{NMR}\left(\mathrm{CDCl}_{3}, 200 \mathrm{MHz}\right) \delta 0.84$ $(\mathrm{t}, \mathrm{J}=6.8 \mathrm{~Hz}, 3 \mathrm{H}), 1.18(\mathrm{~s}, 9 \mathrm{H}), 1.31-1.46(\mathrm{~m}, 10 \mathrm{H}), 2.07$ (br s, $1 \mathrm{H}$ ), 3.36-3.40 (m, $1 \mathrm{H}), 3.48-3.56(\mathrm{~m}, 2 \mathrm{H}) ;{ }^{13} \mathrm{C} N M R$ $\left(\mathrm{CDCl}_{3}, 50 \mathrm{MHz}\right) \delta 14.0,22.6,25.5,28.7,29.5,31.8,33.6,65.2$, 71.6, 73.9; HRMS calcd for $\mathrm{C}_{12} \mathrm{H}_{27} \mathrm{O}_{2}(\mathrm{M}+1) 203.2011$, found 203.2021.

3-tert-Butoxy-3-phenylpropan-1-ol (5c). In a manner similar to that described in the general procedure, a mixture of $4 \mathrm{c}(93 \mathrm{mg}, 0.5 \mathrm{mmol})$ and $\mathrm{MeMgl}\left(1.0 \mathrm{~mL}, 2.0 \mathrm{M}\right.$ in $\mathrm{Et}_{2} \mathrm{O}$, $2.0 \mathrm{mmol}$ ) was converted to $5 \mathrm{c}(84 \mathrm{mg}, 80 \%):{ }^{1} \mathrm{H} \mathrm{NMR}\left(\mathrm{CDCl}_{3}\right.$, $200 \mathrm{MHz}) \delta 1.14(\mathrm{~s}, 9 \mathrm{H}), 1.90(\mathrm{br} \mathrm{q}, \mathrm{J}=6.0 \mathrm{~Hz}, 2 \mathrm{H}), 3.05(\mathrm{br}$ $\mathrm{t}, \mathrm{J}=6.0 \mathrm{~Hz}, 1 \mathrm{H}), 3.70(\mathrm{br} \mathrm{q}, \mathrm{J}=6.0 \mathrm{~Hz}, 2 \mathrm{H}), 4.77(\mathrm{br} \mathrm{t}, \mathrm{J}$ $=6.0 \mathrm{~Hz}, 1 \mathrm{H}), 7.21-7.34(\mathrm{~m}, 5 \mathrm{H}) ;{ }^{13} \mathrm{C} \mathrm{NMR}\left(\mathrm{CDCl}_{3}, 50 \mathrm{MHz}\right)$ $\delta$ 28.6, 41.5, 60.9, 74.4, 75.1, 125.9, 126.8, 128.2, 145.4; HRMS calcd for $\mathrm{C}_{13} \mathrm{H}_{20} \mathrm{O}_{2}$ 208.1463, found 208.1468.

2-Deoxy-O5-tert-butyl-D-threo-pent-1-enose Trimethylene Dithioacetal (7). In a manner similar to that described in the general procedure, 6 (134 $\mathrm{mg}, 0.51 \mathrm{mmol}$ ) in benzene $(20 \mathrm{~mL})$ was allowed to react with $\mathrm{MeMgl}(2.0 \mathrm{~mL}, 2.0$ $\mathrm{mmol}$ ) under refluxing conditions for $28 \mathrm{~h}$ to afford 7 (112 mg, $78 \%$ ): $[\alpha]_{\mathrm{D}}^{32}+7.7^{\circ}$ (c $0.03, \mathrm{CHCl}_{3}$ ); IR (neat) $v 3443 \mathrm{~cm}^{-1} ;{ }^{1} \mathrm{H}$ NMR $\left(\mathrm{CDCl}_{3}, 300 \mathrm{MHz}\right) \delta 1.17(\mathrm{~s}, 9 \mathrm{H}), 2.09-2.16(\mathrm{~m}, 2 \mathrm{H})$, 2.77-2.95 (m, $5 \mathrm{H}), 3.04(\mathrm{~d}, \mathrm{~J}=3.2 \mathrm{~Hz}, 1 \mathrm{H}), 3.36(\mathrm{dd}, \mathrm{J}=$ $3.5,9.2 \mathrm{~Hz}, 1 \mathrm{H}), 3.44(\mathrm{dd}, \mathrm{J}=3.5,9.2 \mathrm{~Hz}, 1 \mathrm{H}), 3.52-3.54$ $(\mathrm{m}, 1 \mathrm{H}), 4.59-4.64(\mathrm{~m}, 1 \mathrm{H}), 5.91(\mathrm{~d}, \mathrm{~J}=8.5 \mathrm{~Hz}, 1 \mathrm{H}) ;{ }^{13} \mathrm{C}$ NMR $\left(\mathrm{CDCl}_{3}, 75 \mathrm{MHz}\right) \delta 24.5,27.4,29.1,29.4,63.4,70.0,72.9$, 73.6, 129.7, 132.7; HRMS calcd for $\mathrm{C}_{12} \mathrm{H}_{22} \mathrm{O}_{3} \mathrm{~S}_{2} 278.1010$, found 278.1017.

O $^{1-t e r t-B ~ u t y l-O 3}, \mathrm{O}^{4}$-isopropylidene-L-threitol (11). A solution of $10(4.0 \mathrm{~g}, 19.8 \mathrm{mmol})$ and $\mathrm{MeMgl}$ ( $2 \mathrm{M}$ solution in ether, 4 equiv) in dry benzene $(80 \mathrm{~mL})$ was stirred at room temperature for 5 days. Saturated $\mathrm{NH}_{4} \mathrm{Cl}(50 \mathrm{~mL})$ was introduced, and the mixture was extracted with ether $(3 \times$ $100 \mathrm{~mL}$ ). The organic layer was washed with brine and dried $\left(\mathrm{MgSO}_{4}\right)$, and the solvent was removed in vacuo. The residue obtained was chromatographed on silica gel (hexane/EtOAc $=9 / 1)$ to afford $11(2.1 \mathrm{~g}, 48 \%)$ as a colorless liquid: $[\alpha]_{D}{ }^{26}$ $+4.9^{\circ}$ (c 2.9, $\mathrm{CHCl}_{3}$ ); IR (neat) $v 3450 \mathrm{~cm}^{-1}$; ${ }^{1} \mathrm{H} \mathrm{NMR}\left(\mathrm{CDCl}_{3}\right.$, $300 \mathrm{MHz}) \delta 1.11(\mathrm{~s}, 9 \mathrm{H}), 1.29(\mathrm{~s}, 3 \mathrm{H}), 1.35(\mathrm{~s}, 3 \mathrm{H}), 2.53(\mathrm{br}$ s, $1 \mathrm{H}), 3.32(\mathrm{dd}, \mathrm{J}=6.0,8.9 \mathrm{~Hz}, 1 \mathrm{H}), 3.38(\mathrm{dd}, \mathrm{J}=6.0,8.9$ $\mathrm{Hz}, 1 \mathrm{H}), 3.63(\mathrm{q}, \mathrm{J}=6.0 \mathrm{~Hz}, 1 \mathrm{H}), 3.78-3.83(\mathrm{dd}, \mathrm{J}=6.0,8.1$ $\mathrm{Hz}, 1 \mathrm{H}), 3.97-4.01(\mathrm{dd}, \mathrm{J}=6.0,8.1 \mathrm{~Hz}, 1 \mathrm{H}), 4.11(\mathrm{q}, \mathrm{J}=6.0$ $\mathrm{Hz}, 1 \mathrm{H}) ;{ }^{13} \mathrm{C} \mathrm{NMR}\left(\mathrm{CDCl}_{3}, 75 \mathrm{MHz}\right) \delta 25.2,26.2,27.3,62.8$, $65.8,71.2,73.1,76.9,108.9$; HRMS calcd for $\mathrm{C}_{10} \mathrm{H}_{19} \mathrm{O}_{4}(\mathrm{M}-$ $\left.\mathrm{CH}_{3}\right)$ 203.1283, found 203.1288.

2(R)-Amino-1-tert-butoxy-03,04-isopropylidene-3(S),4butanediol (8). To an ice-cooled solution of $\mathbf{1 1}$ (1.84 g, 8.43 $\mathrm{mmol})$ and $\mathrm{Et}_{3} \mathrm{~N}(1.71 \mathrm{~g}, 16.9 \mathrm{mmol})$ in $\mathrm{CH}_{2} \mathrm{Cl}_{2}(30 \mathrm{~mL})$ was added a solution of $\mathrm{MsCl}(1.45 \mathrm{~g}, 12.6 \mathrm{mmol})$ in $\mathrm{CH}_{2} \mathrm{Cl}_{2}$ (30 $\mathrm{mL}$ ) dropwise over a period of $30 \mathrm{~min}$. After the addition was over, the reaction mixture was warmed to room temperature and stirred for $24 \mathrm{~h}$, and the reaction was then quenched with $\mathrm{HCl}(10 \%) . \mathrm{CH}_{2} \mathrm{Cl}_{2}$ (50 mL) was introduced, and the organic layer was washed with $\mathrm{NaOH}(10 \%)$, water, and brine and dried $\left(\mathrm{MgSO}_{4}\right)$, and the solvent was evaporated in vacuo. The residue was chromatographed on silica gel (hexane/EtOAc 9/1) to yield the corresponding mesylate as a colorless liquid (2.3 g, 92\%): $[\alpha]_{D}{ }^{26}-6.0^{\circ}$ (c 2.0, $\left.\mathrm{CHCl}_{3}\right) ;{ }^{1} \mathrm{H} \mathrm{NMR}\left(\mathrm{CDCl}_{3}, 300 \mathrm{MHz}\right)$ $\delta 1.16(\mathrm{~s}, 9 \mathrm{H}), 1.33(\mathrm{~s}, 3 \mathrm{H}), 1.41(\mathrm{~s}, 3 \mathrm{H}), 3.10(\mathrm{~s}, 3 \mathrm{H}), 3.53$ $(\mathrm{dd}, \mathrm{J}=4.8,10.5 \mathrm{~Hz}, 1 \mathrm{H}), 3.61(\mathrm{dd}, \mathrm{J}=6.6,10.5 \mathrm{~Hz}, 1 \mathrm{H})$, $3.89(\mathrm{dd}, \mathrm{J}=6.6,9.0 \mathrm{~Hz}, 1 \mathrm{H}), 4.05(\mathrm{dd}, \mathrm{J}=6.6,9.0 \mathrm{~Hz}, 1 \mathrm{H})$, $4.25(\mathrm{q}, \mathrm{J}=6.6 \mathrm{~Hz}, 1 \mathrm{H}), 4.61(\mathrm{dt}, \mathrm{J}=4.8,6.6 \mathrm{~Hz}, 1 \mathrm{H}) ;{ }^{13} \mathrm{C}$ $\mathrm{NMR}\left(\mathrm{CDCl}_{3}, 75 \mathrm{MHz}\right) \delta 25.3,26.1,27.3,38.6,61.5,65.5,73.8$, 75.2, 82.0, 109.6; HRMS calcd for $\mathrm{C}_{11} \mathrm{H}_{21} \mathrm{O}_{6} \mathrm{~S}\left(\mathrm{M}-\mathrm{CH}_{3}\right)$ 281.1058, found 281.1046.

A solution of the mesylate $(2.3 \mathrm{~g}, 7.76 \mathrm{mmol})$ and sodium azide $(1.0 \mathrm{~g}, 15.4 \mathrm{mmol})$ in dry DMF $(60 \mathrm{~mL})$ was stirred at $130^{\circ} \mathrm{C}$ for $24 \mathrm{~h}$, cooled to room temperature, diluted with water $(300 \mathrm{~mL})$, and extracted with ether $(3 \times 200 \mathrm{~mL})$. The organic layer was washed with brine and dried $\left(\mathrm{MgSO}_{4}\right)$, and the solvent was evaporated in vacuo to give crude azide as a col orless liquid $(1.23 \mathrm{~g}, 65 \%)$ : IR (neat) $v 2097 \mathrm{~cm}^{-1} ;{ }^{1} \mathrm{H}$ NMR $\left(\mathrm{CDCl}_{3}, 300 \mathrm{MHz}\right) \delta 1.13(\mathrm{~s}, 9 \mathrm{H}), 1.31(\mathrm{~s}, 3 \mathrm{H}), 1.40(\mathrm{~s}, 3 \mathrm{H})$, $3.40-3.46(m, 1 \mathrm{H}), 3.53-3.63(\mathrm{~m}, 2 \mathrm{H}), 3.83-3.92(\mathrm{~m}, 1 \mathrm{H})$, 3.97-4.06 (m, $2 \mathrm{H}) ;{ }^{13} \mathrm{C} \mathrm{NMR}\left(\mathrm{CDCl}_{3}, 75 \mathrm{MHz}\right) \delta 25.2,26.4$, 27.3, 62.3, 63.2, 66.6, 73.6, 75.1, 109.5; HRMS calcd for $\mathrm{C}_{10} \mathrm{H}_{18} \mathrm{O}_{3} \mathrm{~N}_{3}\left(\mathrm{M}-\mathrm{CH}_{3}\right)$ 228.1348, found 228.1340 .

A suspension of the azide $(2.0 \mathrm{~g}, 8.2 \mathrm{mmol})$ in absolute $\mathrm{EtOH}$ $(70 \mathrm{~mL})$ and $\mathrm{Pd} / \mathrm{C}(10 \%, 200 \mathrm{mg})$ was stirred under an atmosphere of $\mathrm{H}_{2}$ for $8 \mathrm{~h}$. The reaction mixture was filtered over Celite and washed with $\mathrm{EtOH}$. The solvent was removed in vacuo, and the residue was chromatographed on silica gel $\left(2 \% \mathrm{MeOH}\right.$ in $\left.\mathrm{CHCl}_{3}\right)$ to afford 8 as a colorless liquid $(1.41 \mathrm{~g}$, 79\%): $[\alpha]_{D}{ }^{26}-4.2^{\circ}$ (c 5.0, $\mathrm{CHCl}_{3}$ ); IR (neat) v $3376,3310 \mathrm{~cm}^{-1}$; ${ }^{1} \mathrm{H}$ NMR $\left(\mathrm{CDCl}_{3}, 300 \mathrm{MHz}\right) \delta 1.14(\mathrm{~s}, 9 \mathrm{H}), 1.31(\mathrm{~s}, 3 \mathrm{H}), 1.37$ $(\mathrm{s}, 3 \mathrm{H}), 1.62(\mathrm{~s}, 2 \mathrm{H}), 2.96-3.02(\mathrm{~m}, 1 \mathrm{H}), 3.23(\mathrm{dd}, \mathrm{J}=6.6$, $9.0 \mathrm{~Hz}, 1 \mathrm{H}), 3.46(\mathrm{dd}, \mathrm{J}=6.6,9.0 \mathrm{~Hz}, 1 \mathrm{H}), 3.80-3.87(\mathrm{~m}, 1$ $\mathrm{H}), 3.95-4.02(\mathrm{~m}, 2 \mathrm{H}) ;{ }^{13} \mathrm{C} \mathrm{NMR}\left(\mathrm{CDCl}_{3}, 75 \mathrm{MHz}\right) \delta 25.3,26.6$, 27.5, 53.3, 63.4, 66.1, 72.8, 77.5, 108.6; HRMS calcd for $\mathrm{C}_{11} \mathrm{H}_{24} \mathrm{O}_{3} \mathrm{~N}\left(\mathrm{M}^{+}+1\right)$ 218.1756, found 218.1727.

1,4-Bis-tert-butoxy-3(R)-amino-2(S)-butanol (9). To a solution of $\mathrm{MeMgl}$ in ether $(1.8 \mathrm{~mL}, 2.0 \mathrm{M}$ solution in ether) was added 8 (100 $\mathrm{mg}, 0.46 \mathrm{mmol}$ ) under $\mathrm{N}_{2}$ atmosphere. The ether was removed under reduced pressure. Tothis was added dry benzene $(5.0 \mathrm{~mL})$, the resulting reaction mixture was stirred at $60^{\circ} \mathrm{C}$ for $48 \mathrm{~h}$ and cooled to room temperature, and $\mathrm{MeOH}$ was added to quench the excess Grignard reagent. The solvent was removed in vacuo, and the residue was chromatographed on silica gel $\left(3 \% \mathrm{MeOH}\right.$ in $\left.\mathrm{CHCl}_{3}\right)$ to afford 9 as a white solid (58 mg, 54\%). F urther crystallized from hexane to yield colorless needles: $\mathrm{mp} 81-82{ }^{\circ} \mathrm{C}$; $[\alpha]_{\mathrm{D}}{ }^{25}+3.7^{\circ}$ (c 1.5, $\left.\mathrm{CHCl}_{3}\right)$; IR ( $\left.\mathrm{KBr}\right) v 3357,3284,3158 \mathrm{~cm}^{-1} ;{ }^{1} \mathrm{H} \mathrm{NMR}\left(\mathrm{CDCl}_{3}\right.$, $300 \mathrm{MHz}) \delta 1.13(\mathrm{~s}, 18 \mathrm{H}), 2.48(\mathrm{~s}, 3 \mathrm{H}), 2.93-2.99(\mathrm{~m}, 1 \mathrm{H})$, $3.31-3.48(\mathrm{~m}, 4 \mathrm{H}), 3.59(\mathrm{q}, \mathrm{J}=6.0 \mathrm{~Hz}, 1 \mathrm{H}) ;{ }^{13} \mathrm{C} \mathrm{NMR}\left(\mathrm{CDCl}_{3}\right.$ $75 \mathrm{MHz}) \delta 27.4,53.2,63.2,63.7,72.6,73.0$; HRMS calcd for $\mathrm{C}_{12} \mathrm{H}_{28} \mathrm{O}_{3} \mathrm{~N}\left(\mathrm{M}^{+}+1\right) 234.2069$, found 234.2055. Anal. Calcd for $\mathrm{C}_{12} \mathrm{H}_{27} \mathrm{O}_{3} \mathrm{~N}$ : C, 61.77; $\mathrm{H}, 11.66 ; \mathrm{N}, 6.0$. Found $\mathrm{C}, 61.28, \mathrm{H}$, $11.21, \mathrm{~N}, 5.38$.

$\mathrm{O}^{1}$-tert-B utyl-O3, $\mathrm{O}^{4}$-dimethyl-O ${ }^{5}, \mathrm{O}^{6}$-isopropylidene-Dmannitol (13). Under $\mathrm{N}_{2}$ atmosphere, to a benzene solution $(40 \mathrm{~mL})$ of $12^{16}(0.87 \mathrm{~g}, 3.0 \mathrm{mmol})$ was added $\mathrm{MeMgl}(6 \mathrm{~mL}$, $2 \mathrm{M}$ in ether, $12 \mathrm{mmol}$ ). The mixture was refluxed for $22 \mathrm{~h}$. Saturated $\mathrm{NH}_{4} \mathrm{Cl}(40 \mathrm{~mL})$ was added, and the mixture was extracted with ether $(40 \mathrm{~mL} \times 3)$. The organic layer was washed with $\mathrm{NaOH}(10 \%, 40 \mathrm{~mL})$ and brine and then dried $\left(\mathrm{MgSO}_{4}\right)$. The solvent was evaporated in vacuo, and the residue was chromatographed on silica gel (hexane/EtOAc 4/1) to give 13 as a colorless liquid $\left(0.75 \mathrm{~g}, 82 \%\right.$ ): $[\alpha]_{\mathrm{D}}^{27}+12.5^{\circ}$ (c 0.05 , $\left.\mathrm{CHCl}_{3}\right) ;{ }^{1} \mathrm{H} \mathrm{NMR}\left(\mathrm{CDCl}_{3}, 300 \mathrm{MHz}\right) \delta 1.18(\mathrm{~s}, 9 \mathrm{H}), 1.32(\mathrm{~s}, 3$ $\mathrm{H}), 1.38(\mathrm{~s}, 3 \mathrm{H}), 2.64(\mathrm{~d}, \mathrm{~J}=6.4 \mathrm{~Hz}, 1 \mathrm{H}), 3.28(\mathrm{dd}, \mathrm{J}=1.8$, $8.4 \mathrm{~Hz}, 1 \mathrm{H}), 3.41(\mathrm{~s}, 3 \mathrm{H}), 3.45(\mathrm{dd}, \mathrm{J}=5.2,8.9 \mathrm{~Hz}, 1 \mathrm{H}), 3.50$ $(\mathrm{s}, 3 \mathrm{H}), 3.55(\mathrm{dd}, \mathrm{J}=3.6,8.9 \mathrm{~Hz}, 1 \mathrm{H}), 3.61(\mathrm{dd}, \mathrm{J}=1.8,6.3$ $\mathrm{Hz}, 1 \mathrm{H}), 3.73-3.82(\mathrm{~m}, 1 \mathrm{H}), 3.94(\mathrm{dd}, \mathrm{J}=6.3,8.0 \mathrm{~Hz}, 1 \mathrm{H})$, $4.06(\mathrm{dd}, \mathrm{J}=6.3,8.0 \mathrm{~Hz}, 1 \mathrm{H}), 4.15(\mathrm{q}, \mathrm{J}=6.3 \mathrm{~Hz}, 1 \mathrm{H}) ;{ }^{13} \mathrm{C}$ NMR $\left(\mathrm{CDCl}_{3}, 75 \mathrm{MHz}\right) \delta 25.5,26.6,27.5,60.1,60.9,62.1,66.7$, 69.3, 73.2, 75.9, 80.7, 80.8, 108.4. Anal. Calcd for $\mathrm{C}_{15} \mathrm{H}_{30} \mathrm{O}_{6}$ : C, 58.80; H, 9.87. Found C, 58.65; H, 9.87.

$\mathrm{O}^{1}, \mathrm{O}^{6}$-Bis-tert-butyl-O3, $\mathrm{O}^{4}$-dimethyl-D-mannitol (14). Under $\mathrm{N}_{2}$ atmosphere, to a solution of $\mathrm{MeMgl}(30 \mathrm{~mL}, 1.7 \mathrm{M}$ in

(14) Matsuda, M.; Sakatoku, S.; Higuchi, M.; Matsumura, H.; Yano, W. Suzuka Kogyo Koto Semmon Gakko Kiyo 1977, 10, 151; Chem. Abstr. 1978, 88, 104822.

(15) Lauterbach, G.; Posselt, G.; Schaefer, R.; Schnurpfeil, D. J Prakt. Chem. 1981, 323, 101; Chem. Abstr. 1981, 95, 60913.

(16) Kuszmann, J . Carbohydr. Res. 1979, 71, 123. 
toluene, $51 \mathrm{mmol}$ ) was added $\mathbf{1 2}$ (1.49 g in $10 \mathrm{~mL}$ toluene, 5.13 $\mathrm{mmol}$ ). The mixture was refluxed for $72 \mathrm{~h}$ and worked up in a similar manner as described above to give $\mathbf{1 4}$ as a colorless liquid $\left(1.25 \mathrm{~g}, 76 \%\right.$ ): $[\alpha]_{\mathrm{D}}{ }^{28}+10.1^{\circ}$ (c $\left.0.07, \mathrm{CHCl}_{3}\right) ;{ }^{1} \mathrm{H} \mathrm{NMR}$ $\left(\mathrm{CDCl}_{3}, 300 \mathrm{MHz}\right) \delta 1.19(\mathrm{~s}, 18 \mathrm{H}), 2.67(\mathrm{~d}, \mathrm{~J}=6.4 \mathrm{~Hz}, 2 \mathrm{H})$, 3.46-3.53 (m, $10 \mathrm{H}$, embodied a singlet at $\delta 3.47(6 \mathrm{H})), 3.58$ $(\mathrm{dd}, \mathrm{J}=3.6,8.8 \mathrm{~Hz}, 2 \mathrm{H}), 3.76-3.84(\mathrm{~m}, 2 \mathrm{H}) ;{ }^{13} \mathrm{C} \mathrm{NMR}\left(\mathrm{CDCl}_{3}\right.$, $75 \mathrm{MHz}) \delta 27.5,60.1,62.2,69.4,73.1,80.1$; HRMS calcd for $\mathrm{C}_{16} \mathrm{H}_{35} \mathrm{O}_{6}(\mathrm{M}+1) 323.2433$, found 323.2437.

$\mathrm{O}^{2}, \mathrm{O}^{3}$-I sopropylidene-O5-tert-butyl-D-xylose Diethyl Dithioacetal (16a). F ol lowing the general procedure, 15a (171 $\mathrm{mg}, 0.51 \mathrm{mmol})$ in benzene $(20 \mathrm{~mL})$ was allowed to react with $\mathrm{MeMgl}(2.0 \mathrm{~mL}, 2.0 \mathrm{mmol})$ under $60^{\circ} \mathrm{C}$ for $14 \mathrm{~h}$ to afford $\mathbf{1 6 a}$ (142 mg, 79\%) $[\alpha]_{\mathrm{D}}^{32}-46.5^{\circ}$ (c $0.05, \mathrm{CHCl}_{3}$ ); IR (neat) $v 3479$ $\mathrm{cm}^{-1}$; ${ }^{1 \mathrm{H}} \mathrm{NMR}\left(\mathrm{CDCl}_{3}, 300 \mathrm{MHz}\right) \delta 1.12(\mathrm{~s}, 9 \mathrm{H}), 1.16-1.21$ (two overlapping triplets, $6 \mathrm{H}), 1.35(\mathrm{~s}, 3 \mathrm{H}), 1.38(\mathrm{~s}, 3 \mathrm{H}), 2.38$ $(\mathrm{d}, \mathrm{J}=6.2 \mathrm{~Hz}, 1 \mathrm{H}), 2.59-2.71(\mathrm{~m}, 4 \mathrm{H}), 3.33-3.42(\mathrm{~m}, 2 \mathrm{H})$, 3.76-3.79 (m, 1 H), $3.84(\mathrm{~d}, \mathrm{~J}=5.4 \mathrm{~Hz}, 1 \mathrm{H}), 4.08(\mathrm{dd}, \mathrm{J}=$ 2.7, 7.6 Hz, $1 \mathrm{H}), 4.33(\mathrm{dd}, \mathrm{J}=5.4,7.6 \mathrm{~Hz}, 1 \mathrm{H}) ;{ }^{13} \mathrm{C}$ NMR $\left(\mathrm{CDCl}_{3}, 50 \mathrm{MHz}\right) \delta 14.3,14.4,25.0,25.4,27.1,27.2,27.5,53.0$ 63.7, 70.0, 73.4, 79.6, 79.7, 109.8; HRMS calcd for $\mathrm{C}_{16} \mathrm{H}_{32} \mathrm{O}_{4} \mathrm{~S}_{2}$ 352.1742 , found 352.1750 .

$\mathrm{O}^{2}, \mathrm{O}^{3}$-I sopropylidene-05-tert-butyl-D-xylose Trimethylene Dithioacetal (16b). In a manner similar to that described in the general procedure, 15b (164 mg, $0.51 \mathrm{mmol}$ ) in benzene $(20 \mathrm{~mL})$ was allowed to react with MeMgl $(2.0 \mathrm{~mL}$, $2.0 \mathrm{mmol}$ ) under $60{ }^{\circ} \mathrm{C}$ for $18 \mathrm{~h}$ to afford $\mathbf{1 6 b}$ (128 $\mathrm{mg}, 75 \%$ ): $[\alpha]_{\mathrm{D}^{32}}-13.9^{\circ}$ (c $0.05, \mathrm{CHCl}_{3}$ ); IR (neat) $v 3479 \mathrm{~cm}^{-1}$; ${ }^{1} \mathrm{H} \mathrm{NMR}$ $\left(\mathrm{CDCl}_{3}, 300 \mathrm{MHz}\right) \delta 1.18(\mathrm{~s}, 9 \mathrm{H}), 1.41(\mathrm{~s}, 3 \mathrm{H}), 1.43(\mathrm{~s}, 3 \mathrm{H})$, $1.97-2.04(\mathrm{~m}, 2 \mathrm{H}), 2.35(\mathrm{~d}, \mathrm{~J}=6.0 \mathrm{~Hz}, 1 \mathrm{H}), 2.72-2.80(\mathrm{~m}, 2$ $H), 2.90-2.98(m, 2 H), 3.38-3.47(m, 2 H), 3.80-3.83(m, 1$ $\mathrm{H}), 4.04(\mathrm{~d}, \mathrm{~J}=5.4 \mathrm{~Hz}, 1 \mathrm{H}), 4.09(\mathrm{dd}, \mathrm{J}=2.7,7.5 \mathrm{~Hz}, 1 \mathrm{H})$, $4.41(\mathrm{dd}, \mathrm{J}=5.4,7.5 \mathrm{~Hz}, 1 \mathrm{H}) ;{ }^{13} \mathrm{C} N M R\left(\mathrm{CDCl}_{3}, 75 \mathrm{MHz}\right) \delta$ 25.7, 27.0, 27.1, 27.5, 28.7, 29.0, 47.7, 63.7, 70.0, 73.4, 78.8, 79.3, 110.0; HRMS calcd for $\mathrm{C}_{15} \mathrm{H}_{28} \mathrm{O}_{4} \mathrm{~S}_{2}$ 336.1429, found 336.1417.

2-Deoxy-03,06-bis-tert-butyl-D-arabino-hexose Diethyl Dithioacetal (18). In a manner similar to that described in the general procedure, $\mathbf{1 7}(178 \mathrm{mg}, 0.51 \mathrm{mmol})$ in benzene (20 $\mathrm{mL}$ ) was allowed to react with $\mathrm{MeMgl}(2.0 \mathrm{~mL}, 2.0 \mathrm{mmol})$ under refluxing conditions for $34 \mathrm{~h}$ to give 18 (127 $\mathrm{mg}, 65 \%)$ : $[\alpha]_{\mathrm{D}}{ }^{32}-17.1^{\circ}\left(\mathrm{c} 0.05, \mathrm{CHCl}_{3}\right) ;{ }^{1} \mathrm{H} \mathrm{NMR}\left(\mathrm{CDCl}_{3}, 300 \mathrm{MHz}\right) \delta$ $1.20(\mathrm{~s}, 9 \mathrm{H}), 1.25(\mathrm{~s}, 9 \mathrm{H}), 1.21-1.32$ (two overlapping triplets, $6 \mathrm{H}$ ), 1.93 (dt, J = 7.2, $14.4 \mathrm{~Hz}, 1 \mathrm{H}$ ), 2.27 (ddd, J = 6.2, 7.2, $14.4 \mathrm{~Hz}, 1 \mathrm{H}), 2.52-2.74(\mathrm{~m}, 4 \mathrm{H}), 3.34(\mathrm{~d}, \mathrm{~J}=5.0 \mathrm{~Hz}, 1 \mathrm{H})$, $3.48-3.58(\mathrm{~m}, 3 \mathrm{H}), 3.62-3.68(\mathrm{~m}, 2 \mathrm{H}), 3.88(\mathrm{t}, \mathrm{J}=7.2 \mathrm{~Hz}, 1$ $\mathrm{H}), 4.17(\mathrm{dt}, \mathrm{J}=2.5,6.2 \mathrm{~Hz}, 1 \mathrm{H}) ;{ }^{13} \mathrm{C} \mathrm{NMR}\left(\mathrm{CDCl}_{3}, 75 \mathrm{MHz}\right)$ $\delta$ 14.3, 14.4, 23.4, 24.4, 27.4, 28.7, 38.2, 47.7, 65.2, 69.7, 69.9, 73.7, 73.8, 75.2; HRMS calcd for $\mathrm{C}_{18} \mathrm{H}_{38} \mathrm{O}_{4} \mathrm{~S}_{2} 382.2212$, found 382.2212.

2-Deoxy-03,06-di-tert-butyl-D-Iyxo-hexoseDiethyl Dithioacetal (20). In a manner similar to that described in the general procedure, $19(179 \mathrm{mg}, 0.51 \mathrm{mmol})$ in benzene $(20 \mathrm{~mL})$ was allowed to react with $\mathrm{MeMgl}(2.0 \mathrm{~mL}, 2.0 \mathrm{mmol})$ under refluxing conditions for $18 \mathrm{~h}$ to give $\mathbf{2 0}$ (124 mg, 64\%): $[\alpha]_{\mathrm{D}}{ }^{32}$ $-21.3^{\circ}$ (c $0.02, \mathrm{CHCl}_{3}$ ); IR (neat) $v 3447 \mathrm{~cm}^{-1}$; ${ }^{1} \mathrm{H} \mathrm{NMR}\left(\mathrm{CDCl}_{3}\right.$ $300 \mathrm{MHz}) \delta 1.16(\mathrm{~s}, 9 \mathrm{H}$ ), 1.18-1.22 (two overlapping triplets, $6 \mathrm{H}), 1.23(\mathrm{~s}, 9 \mathrm{H}), 1.93-2.11(\mathrm{~m}, 2 \mathrm{H}), 2.51-2.73(\mathrm{~m}, 4 \mathrm{H})$, $2.96(\mathrm{~d}, \mathrm{~J}=5.5 \mathrm{~Hz}, 1 \mathrm{H}), 3.22(\mathrm{~d}, \mathrm{~J}=3.6 \mathrm{~Hz}, 1 \mathrm{H}), 3.43(\mathrm{dd}$, $\mathrm{J}=4.8,9.1 \mathrm{~Hz}, 1 \mathrm{H}), 3.50(\mathrm{dd}, \mathrm{J}=4.8,9.1 \mathrm{~Hz}, 1 \mathrm{H}), 3.67-$ $3.70(\mathrm{~m}, 1 \mathrm{H}), 3.83-3.91(\mathrm{~m}, 2 \mathrm{H}), 3.95-4.02(\mathrm{~m}, 1 \mathrm{H}) ;{ }^{13} \mathrm{C} N \mathrm{NR}$ $\left(\mathrm{CDCl}_{3}, 75 \mathrm{MHz}\right) \delta 14.4,24.0,24.4,27.4,28.9,39.8,47.5,63.7$, $69.3,72.2,72.5,73.4,75.0$; HRMS calcd for $\mathrm{C}_{18} \mathrm{H}_{38} \mathrm{O}_{4} \mathrm{~S}_{2}$ 382.2212, found 382.2209 .

$\mathrm{O}^{3}, \mathrm{O}^{4}, \mathrm{O}^{5}, \mathrm{O}^{6}$-Bis-isopropylidene-O ${ }^{1}$-tert-butyl-D-sorbitol (22). A benzene solution ( $25 \mathrm{~mL})$ of $\mathbf{2 1}^{17}(0.15 \mathrm{~g}, 0.48 \mathrm{mmol})$ was treated with $\mathrm{MeMgl}(2.0 \mathrm{~mL}, 2.0 \mathrm{mmol})$ under reflux for $5 \mathrm{~h}$. After cooling, the mixture was diluted with ether and quenched with saturated $\mathrm{NH}_{4} \mathrm{Cl}$. The organic layer was washed with brine and dried $\left(\mathrm{MgSO}_{4}\right)$. The solvent was removed in vacuo and the residue was chromatographed on

(17) Pressman, B. C.; Anderson, L.; Lardy, H. A. J . Am. Chem. Soc 1950, 72,2404 silica gel (hexane/EtOAc 4/1) to give $22(0.13 \mathrm{~g}, 86 \%)$ : $[\alpha]_{\mathrm{D}}{ }^{23}$ $+7.0^{\circ}\left(\mathrm{c} 14.8, \mathrm{CHCl}_{3}\right) ;{ }^{1} \mathrm{H}$ NMR $\left(\mathrm{CDCl}_{3}, 300 \mathrm{MHz}\right) \delta 1.18(\mathrm{~s}, 9$ $\mathrm{H}), 1.31(\mathrm{~s}, 3 \mathrm{H}), 1.35(\mathrm{~s}, 3 \mathrm{H}), 1.39(\mathrm{~s}, 6 \mathrm{H}), 2.14(\mathrm{~s}, 1 \mathrm{H}), 3.43$ $(\mathrm{d}, \mathrm{J}=6.1 \mathrm{~Hz}, 2 \mathrm{H}), 3.80(\mathrm{dt}, \mathrm{J}=2.6,6.1 \mathrm{~Hz}, 1 \mathrm{H}), 3.91-3.97$ $(\mathrm{m}, 2 \mathrm{H}), 3.99-4.05(\mathrm{~m}, 2 \mathrm{H}), 4.08-4.11(\mathrm{~m}, 1 \mathrm{H}) ;{ }^{13} \mathrm{C} N M R$ $\left(\mathrm{CDCl}_{3}, 75 \mathrm{MHz}\right) \delta 25.3,26.6,26.9,27.2,27.5,63.7,67.7,69.7$, 73.3, 77.1, 77.2, 80.3, 109.4, 109.7; HRMS calcd for $\mathrm{C}_{16} \mathrm{H}_{31} \mathrm{O}_{6}$ $\left(\mathrm{M}^{+}+1\right)$ 319.2120, found 319.2128.

$\mathrm{O}^{3}, \mathrm{O}^{4}, \mathrm{O}^{5}, \mathrm{O}^{6}$-Bis-isopropylidene-0 ${ }^{2}$-benzyl-0 ${ }^{1}$-tert-butylD-sorbitol (23). A THF solution (15 mL) of $22(0.23 \mathrm{~g}, 0.72$ $\mathrm{mmol})$ was treated with $\mathrm{NaH}(0.07 \mathrm{~g}, 2.92 \mathrm{mmol})$ at room temperature for $15 \mathrm{~min}$ followed by benzyl bromide $(0.11 \mathrm{~mL}$, $0.86 \mathrm{mmol}$ ). The mixture was stirred for $16 \mathrm{~h}$, and saturated $\mathrm{NaHCO}_{3}$ (15 mL) was introduced. The organic layer was washed with brine and dried $\left(\mathrm{MgSO}_{4}\right)$. The solvent was removed in vacuo, and the residue was chromatographed on silica gel (hexane/EtOAc 20/1) to give $\mathbf{2 3}(0.24 \mathrm{~g}, 82 \%)$ : $[\alpha]_{\mathrm{D}}{ }^{24}$ +26.9 (c $\left.12, \mathrm{CHCl}_{3}\right), \mathrm{mp} 65-67^{\circ} \mathrm{C} ;{ }^{1} \mathrm{H} \mathrm{NMR}\left(\mathrm{CDCl}_{3}, 300 \mathrm{MHz}\right)$ $\delta 1.18(\mathrm{~s}, 9 \mathrm{H}), 1.32(\mathrm{~s}, 3 \mathrm{H}), 1.35(\mathrm{~s}, 6 \mathrm{H}), 1.38(\mathrm{~s}, 3 \mathrm{H}), 3.55-$ $3.69(\mathrm{~m}, 3 \mathrm{H}), 3.82-3.86(\mathrm{~m}, 1 \mathrm{H}), 4.02-4.10(\mathrm{~m}, 4 \mathrm{H}), 4.60$, $4.83(\mathrm{AB} \mathrm{q}, \mathrm{J}=11.7 \mathrm{~Hz}, 2 \mathrm{H}), 7.21-7.36(\mathrm{~m}, 5 \mathrm{H}) ;{ }^{13} \mathrm{C}$ NMR $\left(\mathrm{CDCl}_{3}, 75 \mathrm{MHz}\right) \delta 25.3,26.6,26.8,27.1,27.5,63.1,67.6,73.2$, 73.4, 77.2, 80.5, 109.3, 109.5, 127.4, 127.6, 128.2, 128.4; HRMS calcd for $\mathrm{C}_{23} \mathrm{H}_{36} \mathrm{O}_{6} 408.2512$, found 408.2522 .

Allyl $\mathrm{O}^{2}, \mathrm{O}^{3} ; \mathrm{O}^{4}, \mathrm{O}^{6}$-Bis-isopropylidene- $\alpha$-D-glucopyranoside (29). To a solution of allyl $\alpha-D$-glucopyranoside ${ }^{18}(3.02 \mathrm{~g}$, $13.7 \mathrm{mmol})$ in dry acetone $(100 \mathrm{~mL})$ was added TsOH $(0.03 \mathrm{~g}$, $0.16 \mathrm{mmol}$ ) and 2-methoxypropene $(8 \mathrm{~mL}, 55 \mathrm{mmol})$, and the reaction was stirred for $2 \mathrm{~h}$ at $20^{\circ} \mathrm{C}$ and quenched with $\mathrm{Et}_{3} \mathrm{~N}$ $(5 \mathrm{~mL})$. The solvent was removed in vacuo, and the residue was chromatographed on silica gel (EtOAc/hexane 1/9) to afford 29 (3.15 g, 76.6\%) as a colorless oil: $[\alpha]_{D}{ }^{27}+86.6^{\circ}$ (c $\left.0.05, \mathrm{CHCl}_{3}\right) ;{ }^{1} \mathrm{H} \mathrm{NMR}\left(\mathrm{CDCl}_{3}, 200 \mathrm{MHz}\right) \delta 1.38(\mathrm{~s}, 3 \mathrm{H}), 1.39$ $(\mathrm{s}, 3 \mathrm{H}), 1.42(\mathrm{~s}, 3 \mathrm{H}), 1.49(\mathrm{~s}, 3 \mathrm{H}), 3.45-3.59(\mathrm{~m}, 2 \mathrm{H}), 3.71-$ $3.88(\mathrm{~m}, 3 \mathrm{H}), 3.97-4.23(\mathrm{~m}, 3 \mathrm{H}), 5.11-5.18(\mathrm{~m}, 2 \mathrm{H}), 5.27(\mathrm{~d}$, $\mathrm{J}=17.2 \mathrm{~Hz}, 1 \mathrm{H}), 5.89(\mathrm{ddt}, \mathrm{J}=5.3,10.9,17.2 \mathrm{~Hz}, 1 \mathrm{H}) ;{ }^{13} \mathrm{C}$ $\mathrm{NMR}\left(\mathrm{CDCl}_{3}, 50 \mathrm{MHz}\right) \delta 19.0,26.3,26.7,28.9,62.2,65.0,68.7$ 73.7, 73.9, 76.7, 96.9, 99.5, 111.3, 117.4, 133.4. Anal. Calcd for $\mathrm{C}_{15} \mathrm{H}_{24} \mathrm{O}_{6}$ : C, 59.98; $\mathrm{H}, 8.05$. Found $\mathrm{C}, 59.94 ; \mathrm{H}, 8.12$.

Allyl $0^{3}$-tert-butyl-O ${ }^{4}, \mathrm{O}^{6}$-isopropylidene- $\alpha$-D-glucopyranoside (30). The ethereal solution of MeMgl $(2.4 \mathrm{~mL}, 2 \mathrm{M}$ ether, $6.1 \mathrm{mmol}$ ) was evacuated to remove ether, and the residue was dissolved in benzene $(175 \mathrm{~mL})$. A solution of $\mathbf{2 9}$ $(0.92 \mathrm{~g}, 3.06 \mathrm{mmol})$ in benzene $(25 \mathrm{~mL})$ was then added, the mixture was stirred at $50-60{ }^{\circ} \mathrm{C}$ for $1.5 \mathrm{~h}$, and the reaction was quenched with $\mathrm{NH}_{4} \mathrm{Cl}$ solution $(50 \mathrm{~mL})$. Organic layer was separated, and the aqueous solution was extracted with ether $(200 \mathrm{~mL})$. The combined organic layers were washed successively with water and brine and dried $\left(\mathrm{MgSO}_{4}\right)$. Solvent was removed in vacuo to yield the residue which was chromatographed on silica gel (EtOAc/hexane 1/4) to afford $30(0.83 \mathrm{~g}$, $86 \%)$ as a col orless oil: $[\alpha]_{\mathrm{D}}{ }^{27}+110.8^{\circ}\left(\mathrm{c} 0.05, \mathrm{CHCl}_{3}\right) ;{ }^{1} \mathrm{H} \mathrm{NMR}$ $\left(\mathrm{CDCl}_{3}, 200 \mathrm{MHz}\right) \delta 1.21(\mathrm{~s}, 9 \mathrm{H}), 1.37(\mathrm{~s}, 3 \mathrm{H}), 1.44(\mathrm{~s}, 3 \mathrm{H})$, $2.06(\mathrm{~d}, \mathrm{~J}=7.9 \mathrm{~Hz}, 1 \mathrm{H}), 3.30-3.55(\mathrm{~m}, 2 \mathrm{H}), 3.55-3.88(\mathrm{~m}, 4$ $\mathrm{H}), 4.04(\mathrm{dd}, \mathrm{J}=6.4,12.8 \mathrm{~Hz}, 1 \mathrm{H}), 4.22(\mathrm{dd}, \mathrm{J}=5.4,12.8 \mathrm{~Hz}$, $1 \mathrm{H}), 4.92(\mathrm{~d}, \mathrm{~J}=3.8 \mathrm{~Hz}, 1 \mathrm{H}), 5.21(\mathrm{dd}, \mathrm{J}=1.5,10.2 \mathrm{~Hz}, 1$ H), $5.29(\mathrm{dd}, \mathrm{J}=1.5,17.3 \mathrm{~Hz}, 1 \mathrm{H}), 5.92(\mathrm{ddt}, \mathrm{J}=5.7,10.2$, $17.3 \mathrm{~Hz}, 1 \mathrm{H}) ;{ }^{13} \mathrm{C} \mathrm{NMR}\left(\mathrm{CDCl}_{3}, 50 \mathrm{MHz}\right) \delta 19.0,29.0,29.3$, 62.5, 64.3, 68.5, 72.2, 72.4, 73.3, 74.5, 98.3, 99.1, 118.0, 133.6; HRMS calcd for $\mathrm{C}_{16} \mathrm{H}_{28} \mathrm{O}_{6} 316.1886$, found 316.1889.

Allyl 2-amino-2-deoxy-04,06-isopropylidene-03-tertbutyl- $\alpha-D$-mannopyranoside (31). Pyridine (1.5 mL, 19.0 $\mathrm{mmol}$ ) was added at $-10^{\circ} \mathrm{C}$ to a solution of $30(3.0 \mathrm{~g}, 9.5 \mathrm{mmol})$ in $\mathrm{CH}_{2} \mathrm{Cl}_{2}(60 \mathrm{~mL})$. After brief stirring, $\mathrm{Tf}_{2} \mathrm{O}(1.2 \mathrm{~mL}, 11.4$ $\mathrm{mmol}$ ) was slowly added over a period of $30 \mathrm{~min}$, and the mixture was stirred for $2 \mathrm{~h}$ at $0{ }^{\circ} \mathrm{C}$. Cold water $(20 \mathrm{~mL})$ was then introduced. The aqueous layer was extracted with ether $(50 \mathrm{~mL})$, and the combined organic layers were dried $\left(\mathrm{MgSO}_{4}\right)$. The solvent was removed in vacuo to yield the crude triflate (3.6 g, $8.8 \mathrm{mmol}, 93 \%)$ which was dissolved in DMF $(60 \mathrm{~mL})$. $\mathrm{NaN}_{3}(2.86 \mathrm{~g}, 44.0 \mathrm{mmol})$ was added, and the mixture was

(18) Talley, E. A.; Vale, M. D.; Yanovsky E. J . Am. Chem. Soc. 1945 67, 2037. 
stirred at $80^{\circ} \mathrm{C}$ for $18 \mathrm{~h}$. Then water was introduced, and the mixture was extracted with ether $(60 \mathrm{~mL})$. The organic layer was successively washed with water and brine and dried $\left(\mathrm{MgSO}_{4}\right)$. The solvent was removed in vacuo to give the residue which was chromatographed on silica gel (EtOAc/hexane 1:4) to afford the corresponding azide $(2.17 \mathrm{~g}, 72.3 \%)$ as a colorless oil: $[\alpha]_{\mathrm{D}} 29+72.4^{\circ}\left(\mathrm{c} 0.05, \mathrm{CHCl}_{3}\right)$; IR $(\mathrm{KBr}) v 2107 \mathrm{~cm}^{-1} ;{ }^{1} \mathrm{H}$ NMR $\left(\mathrm{CDCl}_{3}, 200 \mathrm{MHz}\right) \delta 1.22(\mathrm{~s}, 9 \mathrm{H}), 1.36(\mathrm{~s}, 3 \mathrm{H}), 1.49(\mathrm{~s}$, $3 \mathrm{H}), 3.50-4.05(\mathrm{~m}, 7 \mathrm{H}), 4.13(\mathrm{ddt}, \mathrm{J}=1.2,5.3,12.9 \mathrm{~Hz}, 1$ $\mathrm{H}), 4.50(\mathrm{~d}, \mathrm{~J}=1.2 \mathrm{~Hz}, 1 \mathrm{H}), 5.17-5.32(\mathrm{~m}, 2 \mathrm{H}), 5.88(\mathrm{~m}, 1$ $\mathrm{H}) ;{ }^{13} \mathrm{C} \mathrm{NMR}\left(\mathrm{CDCl}_{3}, 50 \mathrm{MHz}\right) \delta 19.3,28.4,29.2,62.2,65.3$, 65.4, 68.1, 69.3, 70.2, 75.0, 98.4, 99.7, 117.9, 133.4. Anal. Calcd for $\mathrm{C}_{16} \mathrm{H}_{27} \mathrm{~N}_{3} \mathrm{O}_{5}$ : C, 56.29; $\mathrm{H}, 7.97 ; \mathrm{N}, 12.31$. Found $\mathrm{C}, 56.34$; $\mathrm{H}, 8.32 ; \mathrm{N}, 12.14$.

Triphenyl phosphine ${ }^{13}(2.52 \mathrm{~g}, 9.60 \mathrm{mmol})$ was added to a solution of the azide $(3.27 \mathrm{~g}, 9.60 \mathrm{mmol})$ in THF $(80 \mathrm{~mL})$, and the mixture was stirred for $2 \mathrm{~h}$. Water $(0.25 \mathrm{~mL})$ was then added, and the mixture was stirred at ambient temperature for an additional $12 \mathrm{~h}$. Hexane $(50 \mathrm{~mL})$ was introduced, and the slurry was filtered. The filtrate was dried $\left(\mathrm{MgSO}_{4}\right)$, and the solvent was removed in vacuo to give the residue which was chromatographed on silica gel (EtOAc/hexane $1 / 2$ ) to afford 31 (2.34 g, 78\%) as a colorless oil: $[\alpha]_{D}^{29}+57.4^{\circ}$ (c 0.05 , $\left.\mathrm{CHCl}_{3}\right) ;{ }^{1} \mathrm{H} \mathrm{NMR}\left(\mathrm{CDCl}_{3}, 200 \mathrm{MHz}\right) \delta 1.17(\mathrm{~s}, 9 \mathrm{H}), 1.35(\mathrm{~s}, 3$ $\mathrm{H}), 1.46(\mathrm{~s}, 3 \mathrm{H}), 3.11(\mathrm{br}, 1 \mathrm{H}), 3.60-3.85(\mathrm{~m}, 7 \mathrm{H}), 3.39$ (ddt, $\mathrm{J}=1.2,6.1,13.0 \mathrm{~Hz}, 1 \mathrm{H}), 4.13(\mathrm{ddt}, \mathrm{J}=1.2,5.2,13.0 \mathrm{~Hz}, 1$ H), 4.73 (br s, $1 \mathrm{H}), 5.14-5.31(\mathrm{~m}, 2 \mathrm{H}), 5.89$ (ddt, J = 5.5, $10.4,17.3 \mathrm{~Hz}, 1 \mathrm{H}) ;{ }^{13} \mathrm{C} \mathrm{NMR}\left(\mathrm{CDCl}_{3}, 50 \mathrm{MHz}\right) \delta 19.2,28.6$, 29.2, 56.2, 62.5, 65.1, 67.9, 68.6, 69.8, 74.3, 99.5, 100.9, 117.3, 133.9. Anal. Calcd for $\mathrm{C}_{16} \mathrm{H}_{29} \mathrm{NO}_{5}$ : C, 60.93; $\mathrm{H}, 9.27 ; \mathrm{N}, 4.44$. Found C, 60.92; H, 8.99; N, 3.95.

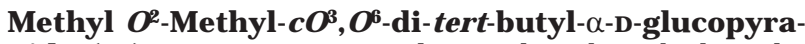
noside (33). In a manner similar to that described in the general procedure, a benzene solution of $32(280 \mathrm{mg}, 0.92$ $\mathrm{mmol})$ and $\mathrm{MeMgl}\left(4.0 \mathrm{~mL}, 2.0 \mathrm{M}\right.$ in $\left.\mathrm{Et}_{2} \mathrm{O}, 8.0 \mathrm{mmol}\right)$ was refluxed for $48 \mathrm{~h}$. After usual workup and chromatographic separation $\left(\mathrm{SiO}_{2}\right.$, hexane/EtOAc 3/1), 33 was obtained (170 mg, $58 \%):[\alpha]_{D}{ }^{29}+76.4^{\circ}\left(\mathrm{c} 0.01, \mathrm{CHCl}_{3}\right) ;{ }^{1} \mathrm{H} \mathrm{NMR}\left(\mathrm{CDCl}_{3}, 200 \mathrm{MHz}\right)$ $\delta 1.24(\mathrm{~s}, 18 \mathrm{H}), 1.79(\mathrm{br}, 1 \mathrm{H}), 3.02(\mathrm{dd}, \mathrm{J}=3.4,9.4 \mathrm{~Hz}, 1 \mathrm{H})$, $3.26(\mathrm{t}, \mathrm{J}=9.0 \mathrm{~Hz}, 1 \mathrm{H}), 3.37(\mathrm{~s}, 3 \mathrm{H}), 3.45(\mathrm{~s}, 3 \mathrm{H}), 3.57(\mathrm{~m}$, $1 \mathrm{H}), 3.60-3.80(\mathrm{~m}, 3 \mathrm{H}), 4.80(\mathrm{~d}, \mathrm{~J}=3.4 \mathrm{~Hz}, 1 \mathrm{H}) ;{ }^{13} \mathrm{C} N M R$ $\left(\mathrm{CDCl}_{3}, 75 \mathrm{MHz}\right) \delta 29.2,29.3,54.8,59.5,62.4,71.4,72.6,72.7$, 75.3, 77.2, 82.1, 97.6; HRMS calcd for $\mathrm{C}_{16} \mathrm{H}_{32} \mathrm{O}_{6} 320.2199$, found 320.2192 .

$0^{1}, O^{2}$-I sopropylidene-O3-methyl-O6-tert-butyl- $\alpha$-D-glucofuranose (35). In a manner similar to that described in the general procedure, a benzene solution of $\mathbf{3 4}(274 \mathrm{mg}, 1.0$ $\mathrm{mmol})$ was treated with $\mathrm{MeMgl}\left(3.0 \mathrm{~mL}, 2.0 \mathrm{M}\right.$ in $\mathrm{Et}_{2} \mathrm{O}, 6.0$ $\mathrm{mmol}$ ) under reflux for $12 \mathrm{~h}$ followed by usual workup to give 35 (140 mg, 55\%): $[\alpha]_{\mathrm{D}}^{28}-29.9^{\circ}$ (c 0.09, $\mathrm{CHCl}_{3}$ ); IR (neat) $v$ $3507 \mathrm{~cm}^{-1}$; $1 \mathrm{H} \mathrm{NMR}\left(\mathrm{CDCl}_{3}, 200 \mathrm{MHz}\right) \delta 1.16(\mathrm{~s}, 9 \mathrm{H}), 1.29$ (s, $3 \mathrm{H}), 1.45(\mathrm{~s}, 3 \mathrm{H}), 2.79(\mathrm{~d}, \mathrm{~J}=5.3 \mathrm{~Hz}, 1 \mathrm{H}), 3.39(\mathrm{~m}, 1 \mathrm{H})$, $3.43(\mathrm{~s}, 3 \mathrm{H}), 3.58(\mathrm{dd}, \mathrm{J}=3.2,8.0 \mathrm{~Hz}, 1 \mathrm{H}), 3.84(\mathrm{~d}, \mathrm{~J}=2.9$ $\mathrm{Hz}, 1 \mathrm{H}), 3.96(\mathrm{~m}, 1 \mathrm{H}), 4.05(\mathrm{dd}, \mathrm{J}=2.9,8.0 \mathrm{~Hz}, 1 \mathrm{H}), 4.53(\mathrm{~d}$, $\mathrm{J}=3.7 \mathrm{~Hz}, 1 \mathrm{H}), 5.85(\mathrm{~d}, \mathrm{~J}=3.7 \mathrm{~Hz}, 1 \mathrm{H}) ;{ }^{13} \mathrm{C} \mathrm{NMR}\left(\mathrm{CDCl}_{3}\right.$, $75 \mathrm{MHz}) \delta 26.1,26.6,27.4,57.95,63.3,67.8,73.2,79.7,81.6$, 84.0, 104.9, 111.5. Anal. Calcd for $\mathrm{C}_{14} \mathrm{H}_{26} \mathrm{O}_{6}$ : C, 57.91; $\mathrm{H}, 9.03$. Found: C, 57.79; $\mathrm{H}, 9.13$.

$\mathbf{O}^{1}, \mathbf{O}^{2}$-I sopropylidene-06-tert-butyl- $\alpha$-D-allofuranose (37). In a manner similar to that described in the general procedure, a benzene solution of $36^{19}$ ( $\left.260 \mathrm{mg}, 1.0 \mathrm{mmol}\right)$ was treated with $\mathrm{MeMgl}\left(2.0 \mathrm{~mL}, 2.0 \mathrm{M}\right.$ in $\left.\mathrm{Et}_{2} \mathrm{O}, 4.0 \mathrm{mmol}\right)$ under reflux for 20 $\mathrm{h}$ followed by usual workup to give $37^{20}$ (150 mg, 54\%): [ $\left.\alpha\right]_{D}{ }^{32}$ $+23.1^{\circ}$ (c 0.04, $\mathrm{CHCl}_{3}$ ); $\mathrm{mp} \mathrm{59-61}{ }^{\circ} \mathrm{C}$; IR (KBr) v 3491, 3364 $\mathrm{cm}^{-1}$; ${ }^{1} \mathrm{H} N M R\left(\mathrm{CDCl}_{3}, 200 \mathrm{MHz}\right) \delta 1.20(\mathrm{~s}, 9 \mathrm{H}), 1.34(\mathrm{~s}, 3 \mathrm{H})$, $1.56(\mathrm{~s}, 3 \mathrm{H}), 2.40(\mathrm{~d}, \mathrm{~J}=4.2 \mathrm{~Hz}, 1 \mathrm{H}), 3.48(\mathrm{dd}, \mathrm{J}=4.8,9.0$ $\mathrm{Hz}, 1 \mathrm{H}), 3.64(\mathrm{dd}, \mathrm{J}=3.4,6.0 \mathrm{~Hz}, 1 \mathrm{H}), 3.73(\mathrm{~d}, \mathrm{~J}=4.7 \mathrm{~Hz}$, $1 \mathrm{H}), 3.89(\mathrm{dd}, \mathrm{J}=3.8,9.0 \mathrm{~Hz}, 1 \mathrm{H}), 3.98(\mathrm{~m}, 1 \mathrm{H}), 4.08(\mathrm{~m}, 1$ $\mathrm{H}), 4.64(\mathrm{t}, \mathrm{J}=4.2 \mathrm{~Hz}, 1 \mathrm{H}), 5.75(\mathrm{~d}, \mathrm{~J}=3.7 \mathrm{~Hz}, 1 \mathrm{H}) ;{ }^{13} \mathrm{C}$ $\mathrm{NMR}\left(\mathrm{CDCl}_{3}, 75 \mathrm{MHz}\right) \delta 26.4,26.7,27.3,62.7,70.1,70.9,74.3$,

(19) (a) Collins, P. M. Tetrahedron 1965, 21, 1809. (b) Baker D. C.; Horton D.; Tindall, C. G., J r. Carbohydr. Res. 1972, 24, 192.

(20) Kawana, M.; Emoto, S. Bull. Chem. Soc. J pn. 1980, 53, 230.
79.6, 80.9, 103.8, 112.9. Anal. Calcd for $\mathrm{C}_{13} \mathrm{H}_{24} \mathrm{O}_{6}$ : C, 56.49; $H, 8.75$. Found: $C, 56.00 ; \mathrm{H}, 8.80$.

$0^{3}$-tert-B utyl-O 6 -methyl-O ${ }^{1}, O^{2}$-isopropylidene- $\alpha-D$-galactopyranose (39). In a manner similar to that described in the general procedure, a toluene solution of $38^{21}(274 \mathrm{mg}$, $1.0 \mathrm{mmol}$ ) was treated with $\mathrm{MeMgl}\left(2.0 \mathrm{~mL}, 2.0 \mathrm{M}\right.$ in $\mathrm{Et}_{2} \mathrm{O}$, $4.0 \mathrm{mmol}$ ) at $60^{\circ} \mathrm{C}$ for $40 \mathrm{~h}$ followed by usual workup to give 39 (150 mg, 52\%): $[\alpha]_{D}{ }^{28}+20.51^{\circ}$ (c 0.4, $\mathrm{CHCl}_{3}$ ); IR (neat) $v$ $3443 \mathrm{~cm}^{-1} ;{ }^{1} \mathrm{H} \mathrm{NMR}\left(\mathrm{CDCl}_{3}, 300 \mathrm{MHz}\right) \delta 1.23(\mathrm{~s}, 9 \mathrm{H}), 1.32(\mathrm{~s}$, $3 \mathrm{H}), 1.48(\mathrm{~s}, 3 \mathrm{H}), 2.84(\mathrm{~d}, \mathrm{~J}=2.9 \mathrm{~Hz}, 1 \mathrm{H}), 3.37(\mathrm{~s}, 3 \mathrm{H}), 3.56$ $(\mathrm{dd}, \mathrm{J}=6.3,10.0 \mathrm{~Hz}, 1 \mathrm{H}), 3.64(\mathrm{dd}, \mathrm{J}=5.8,10.0 \mathrm{~Hz}, 1 \mathrm{H})$, $3.76(\mathrm{t}, \mathrm{J}=4.5 \mathrm{~Hz}, 1 \mathrm{H}), 3.80-3.84(\mathrm{~m}, 1 \mathrm{H}), 3.90-4.03(\mathrm{~m}, 2$ $\mathrm{H}), 5.54(\mathrm{~d}, \mathrm{~J}=1.0 \mathrm{~Hz}, 1 \mathrm{H}) ;{ }^{13} \mathrm{C} \mathrm{NMR}\left(\mathrm{CDCl}_{3}, 75 \mathrm{MHz}\right) \delta$ 26.5, 27.6, 28.5, 59.3, 67.2, 70.3, 71.8, 75.4, 97.3, 108.0. Anal. Calcd for $\mathrm{C}_{14} \mathrm{H}_{26} \mathrm{O}_{6}$ : C, 57.91; $\mathrm{H}, 9.03$. Found: $\mathrm{C}, 57.86 ; \mathrm{H}$, 9.01.

Methyl $\mathrm{O}^{2}, \mathrm{O}^{4}-\mathrm{B}$ is-tert-butyl- $\alpha$-D-mannopyranoside (41). In a manner similar to that described in the general procedure, MeMgl (30 mmol, $30 \mathrm{~mL}$ in $1.0 \mathrm{M}$ ether solution) was evacuated to remove ether. A benzene solution $(30 \mathrm{~mL})$ of $\mathbf{4 0}^{22}$ $(1.37 \mathrm{~g}, 5.0 \mathrm{mmol})$ was then introduced, and the reaction was refluxed for $24 \mathrm{~h}$, quenched with $\mathrm{NH}_{4} \mathrm{Cl}$, and extracted with ether. The organic layer was washed with water and brine and dried $\left(\mathrm{MgSO}_{4}\right)$. The solvent was removed in vacuo, and the residue was chromatographed on silica gel (hexane/EtOAc 7/3) to yield $41(0.78 \mathrm{~g}, 51 \%): \mathrm{mp} 82-83^{\circ} \mathrm{C} ;[\alpha]_{D} 27+4.4^{\circ}$ (c 2.5, $\left.\mathrm{CHCl}_{3}\right)$; IR ( $\left.\mathrm{KBr}\right)$ v 3439, $3377 \mathrm{~cm}^{-1}$; ${ }^{1} \mathrm{H} \mathrm{NMR}(400 \mathrm{MHz}$, $\left.\mathrm{CDCl}_{3}\right) \delta 1.22(\mathrm{~s}, 9 \mathrm{H}), 1.23(\mathrm{~s}, 9 \mathrm{H}), 2.03(\mathrm{t}, \mathrm{J}=6.4 \mathrm{~Hz}, 1 \mathrm{H})$, $2.09(\mathrm{~d}, \mathrm{~J}=9.2 \mathrm{~Hz}, 1 \mathrm{H}), 3.31(\mathrm{~s}, 3 \mathrm{H}), 3.48(\mathrm{ddd}, \mathrm{J}=3.2,5.2$, $8.8 \mathrm{~Hz}, 1 \mathrm{H}), 3.57(\mathrm{dd}, \mathrm{J}=7.2,8.8, \mathrm{~Hz}, 1 \mathrm{H}), 3.65$ (ddd, J = 4.0, 7.6, 9.2 Hz, $1 \mathrm{H}$ ), 3.71 (ddd, J = 5.6, 7.2, $11.6 \mathrm{~Hz}, 1 \mathrm{H}$ ), $3.77-3.83(\mathrm{~m}, 2 \mathrm{H}), 4.60(\mathrm{~d}, \mathrm{~J}=2.0 \mathrm{~Hz}, 1 \mathrm{H}) ;{ }^{13} \mathrm{C} \mathrm{NMR}\left(\mathrm{CDCl}_{3}\right.$, $75 \mathrm{MHz}) \delta$ 28.5, 29.1, 54.8, 62.3, 69.5, 71.5, 71.6, 71.8, 74.8, 75.3, 101.1; HRMS calcd for $\mathrm{C}_{15} \mathrm{H}_{30} \mathrm{O}_{6} 306.2042$, found 306.2047. Anal. Calcd: C, 58.78; H, 9.87. Found: C, 58.77; H, 9.76.

Methyl $\mathrm{O}^{2}$-tert-Butyl-O4, $\mathrm{O}^{6}$-isopropylidene- $\alpha-D$-mannopyranoside (42). In a manner similar to that described in the general procedure, a benzene solution $(50 \mathrm{~mL})$ of $\mathrm{MeMgl}$ $(32.8 \mathrm{mmol})$ and $\mathbf{4 0}(500 \mathrm{mg}, 1.82 \mathrm{mmol})$ was stirred at $40{ }^{\circ} \mathrm{C}$ for $24 \mathrm{~h}$. The mixture was cooled to room temperature, and the reaction was quenched with $\mathrm{NH}_{4} \mathrm{Cl}$ and extracted with ether $(3 \times 50 \mathrm{~mL})$. The organic layer was washed with brine and dried $\left(\mathrm{MgSO}_{4}\right)$. The residue obtained was chromatographed over silica gel (hexane/EtOAc 4/1) to give, in addition to 41 (120 mg, 23\%), 42 (200 mg, 38\%) as a colorless oil: $[\alpha]_{D}{ }^{24}$ $+2.3^{\circ}$ (c 4.0, $\mathrm{CHCl}_{3}$ ); IR (neat) $v 3483 \mathrm{~cm}^{-1}$; ${ }^{1} \mathrm{H} \mathrm{NMR}\left(\mathrm{CDCl}_{3}\right.$ $300 \mathrm{MHz}) \delta 1.20(\mathrm{~s}, 9 \mathrm{H}), 1.33(\mathrm{~s}, 3 \mathrm{H}), 1.51(\mathrm{~s}, 3 \mathrm{H}), 3.37(\mathrm{~s}, 3$ $\mathrm{H}), 3.42(\mathrm{~d}, \mathrm{~J}=1.7 \mathrm{~Hz}, 1 \mathrm{H}), 3.52-3.61(\mathrm{~m}, 2 \mathrm{H}), 3.63-3.69$ $(\mathrm{m}, 2 \mathrm{H}), 4.07-4.12(\mathrm{~m}, 2 \mathrm{H}), 4.86(\mathrm{~s}, 1 \mathrm{H}) ;{ }^{33} \mathrm{C} \mathrm{NMR}\left(\mathrm{CDCl}_{3}\right.$, $75 \mathrm{MHz}) \delta 26.1,27.3,27.9,55.0,63.9,67.3,72.7,74.1,75.1$, 78.0, 98.2, 109.5; HRMS calcd for $\mathrm{C}_{14} \mathrm{H}_{26} \mathrm{O}_{6} 290.1729$, found 290.1732.

Acetonide 46. In a manner similar to that described in the general procedure, a benzene solution $(50 \mathrm{~mL})$ of $\mathrm{MeMgl}(8.0$ $\mathrm{mmol})$ and $43(520 \mathrm{mg}, 2.0 \mathrm{mmol})$ was refluxed for $18 \mathrm{~h}$ followed by usual workup to give 46 (460 mg, 75\%): $[\alpha]_{D}{ }^{28}$ $+47.07^{\circ}\left(\mathrm{c} 0.09, \mathrm{CHCl}_{3}\right) ; \mathrm{mp} 90-92{ }^{\circ} \mathrm{C}$; I R $(\mathrm{KBr}) v 3391 \mathrm{~cm}^{-1}$. ${ }^{1} \mathrm{H}$ NMR $\left(\mathrm{CDCl}_{3}, 300 \mathrm{MHz}\right) \delta 1.14(\mathrm{~s}, 3 \mathrm{H}), 1.21(\mathrm{~s}, 9 \mathrm{H}), 1.34$ $(\mathrm{s}, 3 \mathrm{H}), 1.39(\mathrm{~s}, 3 \mathrm{H}), 2.62(\mathrm{t}, \mathrm{J}=5.2 \mathrm{~Hz}, 1 \mathrm{H}), 3.09(\mathrm{~d}, \mathrm{~J}=9.1$ $\mathrm{Hz}, 2 \mathrm{H}), 3.18(\mathrm{~s}, 1 \mathrm{H}), 3.36(\mathrm{~s}, 3 \mathrm{H}), 3.51(\mathrm{~d}, \mathrm{~J}=9.2 \mathrm{~Hz}, 1 \mathrm{H})$, $3.74(\mathrm{~m}, 1 \mathrm{H}), 4.00(\mathrm{~d}, \mathrm{~J}=9.3 \mathrm{~Hz}, 1 \mathrm{H}), 4.26(\mathrm{~m}, 2 \mathrm{H}) ;{ }^{13} \mathrm{C}$ NMR $(75 \mathrm{MHz}) \delta 25.4,28.1,29.31,58.9,62.1,69.8,73.8,75.7$, 77.9, 78.3. Anal. Calcd for $\mathrm{C}_{15} \mathrm{H}_{30} \mathrm{O}_{6}: \mathrm{C}, 58.79 ; \mathrm{H}, 9.87$. Found: C, 58.52; H, 9.79.

Acetonide 49. I $\mathrm{n}$ a manner similar to that described in the general procedure, a benzene solution $(50 \mathrm{~mL})$ of $\mathrm{MeM} \mathrm{gl}(4.0$ $\mathrm{mmol})$ and $44(260 \mathrm{mg}, 1.0 \mathrm{mmol})$ was refluxed for $18 \mathrm{~h}$ followed by usual workup to give 49 (160 mg, 55\%): $[\alpha]_{\mathrm{D}}{ }^{28}$ $+1.85^{\circ}$ (c $0.01, \mathrm{CHCl}_{3}$ ); $\mathrm{mp} 125-126{ }^{\circ} \mathrm{C}$; IR (KBr) $v 3353 \mathrm{~cm}^{-1}$; ${ }^{1} \mathrm{H}$ NMR $\left(\mathrm{CDCl}_{3}, 300 \mathrm{MHz}\right) \delta 1.15(\mathrm{~s}, 3 \mathrm{H}), 1.18(\mathrm{~s}, 9 \mathrm{H}), 1.37$ (s, $3 \mathrm{H}$ ), 1.49 (s, 3 H), 2.97 (dd, J = 5.1, $7.7 \mathrm{~Hz}, 1 \mathrm{H}$ ), 3.07 (s,

(21) (a) Girard, P.; Kagan, H. Tetrahedron 1971, 27, 5911. (b) Rathbone, E. B.; Stephen, A. M.; Pachler, K. G. R. Carbohydr. Res. 1971, 20, 357. 
$3 \mathrm{H}), 3.22(\mathrm{~d}, \mathrm{~J}=8.6 \mathrm{~Hz}, 1 \mathrm{H}), 3.39(\mathrm{~d}, \mathrm{~J}=8.6 \mathrm{~Hz}, 1 \mathrm{H}), 3.57$ $(\mathrm{t}, \mathrm{J}=8.5 \mathrm{~Hz}, 1 \mathrm{H}), 3.70(\mathrm{~m}, 3 \mathrm{H}), 4.22(\mathrm{dt}, \mathrm{J}=4.9,9.0 \mathrm{~Hz}, 1$ $\mathrm{H}), 4.42(\mathrm{dd}, \mathrm{J}=1.5,6.8 \mathrm{~Hz}, 1 \mathrm{H}) ;{ }^{13} \mathrm{C} \mathrm{NMR}\left(\mathrm{CDCl}_{3}, 75 \mathrm{MHz}\right)$ $\delta$ 20.2, 25.2, 27.2, 27.4, 61.6, 67.3, 72.1, 73.1, 73.6, 74.5, 78.1, 108.2. Anal. Calcd for $\mathrm{C}_{14} \mathrm{H}_{28} \mathrm{O}_{6}$ : $\mathrm{C}, 57.50 ; \mathrm{H}, 9.66$. Found: $\mathrm{C}$, 57.23; H, 9.63.

Acetonide 50. In a manner similar to that described in the general procedure, a benzene solution ( $20 \mathrm{~mL}$ ) of $\mathrm{MeMgl}(20$ $\mathrm{mmol}$ ) and $45^{23}$ ( $\left.1.15 \mathrm{~g}, 5.0 \mathrm{mmol}\right)$ was refluxed for $24 \mathrm{~h}$ followed by usual workup to give $\mathbf{5 0}(0.83 \mathrm{~g}, 63 \%)$ : $\mathrm{mp}$ 62-63 ${ }^{\circ} \mathrm{C} ;[\alpha]_{\mathrm{D}}{ }^{27}+35.5^{\circ}$ (c 4.5, $\left.\mathrm{CHCl}_{3}\right)$; IR (KBr) v $3507 \mathrm{~cm}^{-1}$; ${ }^{1 \mathrm{H}} \mathrm{NMR}$ $\left(\mathrm{CDCl}_{3}, 300 \mathrm{MHz}\right) \delta 1.21(\mathrm{~d}, \mathrm{~J}=7.2 \mathrm{~Hz}, 3 \mathrm{H}), 1.23(\mathrm{~s}, 9 \mathrm{H})$, $1.33(\mathrm{~s}, 3 \mathrm{H}), 1.42(\mathrm{~s}, 3 \mathrm{H}), 2.63(\mathrm{br} \mathrm{s}, 2 \mathrm{H}), 3.64-3.67(\mathrm{~m}, 2 \mathrm{H})$,

(22) Stevens, C. L.; Glinski, R. P.; Taylor, K. G.; Sirokman, F. J . Org. Chem. 1970, 35, 592.

(23) (a) Heyns, K.; Neste, R.; Paal, M. Tetrahedron Lett. 1978, 42, 4011. (b) De J ongh, D. C.; Biemann, K. J . Am. Chem. Soc. 1964, 86, 67. $3.72-3.73(\mathrm{~m}, 2 \mathrm{H}), 4.25(\mathrm{q}, \mathrm{J}=6.0 \mathrm{~Hz}, 1 \mathrm{H}), 4.31(\mathrm{dd}, \mathrm{J}=$ $6.3,7.8 \mathrm{~Hz}, 1 \mathrm{H}) ;{ }^{13} \mathrm{C} \mathrm{NMR}\left(\mathrm{CDCl}_{3}, 75 \mathrm{MHz}\right) \delta 21.3,25.0,27.6$, 28.8, 61.4, 66.6, 72.2, 75.5, 76.6, 77.7, 107.9; HRMS calcd for $\mathrm{C}_{13} \mathrm{H}_{27} \mathrm{O}_{5}(\mathrm{M}+1) 263.1858$, found 263.1857.

Acknowledgment. Support from the National Science Council of the Republic of China is gratefully acknowl edged.

Supporting Information Available: NMR spectra for $\mathbf{5 c}$, 7-9, 11, 14, 16a, b, 18, 20, 22, 23, 29-31, 33, 42, and 50 and the X-ray crystallographic data for $\mathbf{9}$ and $\mathbf{2 3}$ (36 pages). This material is contained in libraries on microfiche, immediately follows this article in the microfilm version of the journal, and can be ordered from the ACS; see any current masthead page for ordering information.

J O981579A 